\title{
Analysis of User Preference with N95 and Powered Air-Purifying Respirators in a Healthcare Work Environment
}

\author{
Brittany Renee Carver \\ West Virginia University, brcarver@mix.wvu.edu
}

Follow this and additional works at: https://researchrepository.wvu.edu/etd

Part of the Biology Commons, Occupational Health and Industrial Hygiene Commons, Operations Research, Systems Engineering and Industrial Engineering Commons, and the Other Public Health Commons

\section{Recommended Citation}

Carver, Brittany Renee, "Analysis of User Preference with N95 and Powered Air-Purifying Respirators in a Healthcare Work Environment" (2019). Graduate Theses, Dissertations, and Problem Reports. 3946. https://researchrepository.wvu.edu/etd/3946

This Thesis is protected by copyright and/or related rights. It has been brought to you by the The Research Repository @ WVU with permission from the rights-holder(s). You are free to use this Thesis in any way that is permitted by the copyright and related rights legislation that applies to your use. For other uses you must obtain permission from the rights-holder(s) directly, unless additional rights are indicated by a Creative Commons license in the record and/ or on the work itself. This Thesis has been accepted for inclusion in WVU Graduate Theses, Dissertations, and Problem Reports collection by an authorized administrator of The Research Repository @ WVU. For more information, please contact researchrepository@mail.wvu.edu. 


\title{
Analysis of User Preference with N95 and Powered Air- Purifying Respirators in a Healthcare Work Environment
}

\section{Brittany Carver}

Thesis submitted to the Statler College of Engineering and Mineral Resources at West Virginia University

in partial fulfillment of the requirement for the degree of

\author{
Master of Science \\ in \\ Industrial Hygiene \\ Xinijan He, Ph.D., Chair \\ Steven Guffey, Ph.D. \\ Anna Allen, MD.
}

Department of Industrial and Management System Engineering

Morgantown, West Virginia
Spring 2019

Keywords: respirators, N95, PAPRs, healthcare Copyright 2019: Brittany Carver 


\section{Abstract \\ Analysis of User Preference with N95 and Powered Air- Purifying Respirators in a healthcare work environment}

\section{Brittany Carver}

For those working in the healthcare field, personal protective equipment is vital. Healthcare workers are often first responders when it comes to dealing with patients who are infected or when a disease outbreak occurs. The Occupational Safety and Health Administration (OSHA) requires all healthcare operations to provide employee protection against blood borne pathogens. With the increase of life-threatening disease outbreaks, such as SARS in 2003 and Ebola in 2014, it is of the upmost importance to make sure respirators are best suited for users and acceptable for long term use. It has been shown through previous studies that due to certain factors, respirator user non-compliance is common. Such factors include but are not limited to headaches, thermal discomfort, eye discomfort, interference with duties, etc. By conducting the current study, data was collected on the above factors based off of user opinions of respirators. This study set out to determine if there was significant difference between sixteen different categories, which included rating respirators. The study included four respirators: one filtering face piece respirator (FFR) and three powered air-purifying respirators (PAPR's). Subjects recruited were healthcare workers and had prior knowledge of respirators. Subjects conducted the study at a simulation laboratory and each subject was instructed to wear each of the four respirators and perform a list of tasks common to HCW's. After completing all tasks, subjects completed a questionnaire based on each respirator. Results showed that the N95 mask was preferred over PAPR's in five of sixteen categories. Within the PAPR's themselves, MAXAIR performed slightly better than Airmate, while Versaflo typically was outperformed by all respirators. 


\section{Acknowledgements}

The author wishes to acknowledge Dr. Xinijan “Kevin” He, Dr. Steven Guffey, Dr. Anna Allen, Huihui Yang, Lauren MacDowell, Dan Summers, and Adam Hoffman for their help with this study. 


\section{Table of Contents}

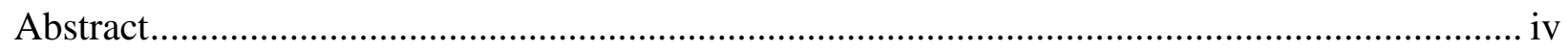

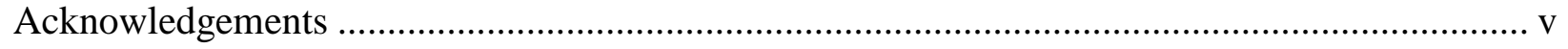

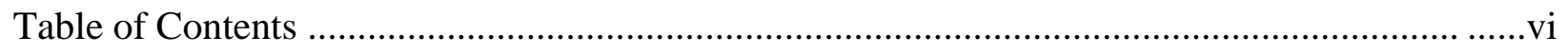

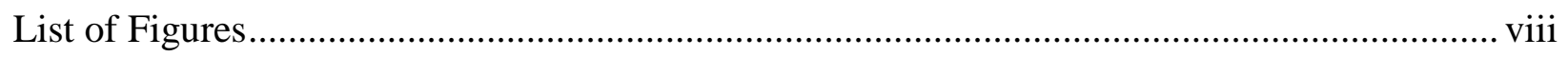

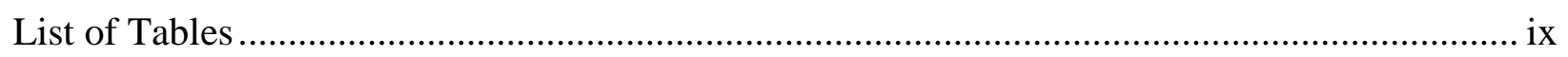

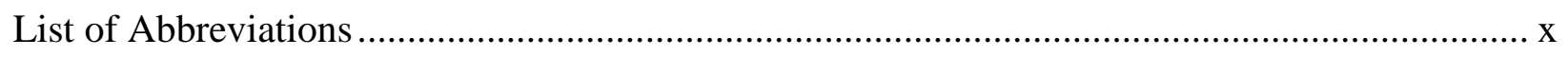

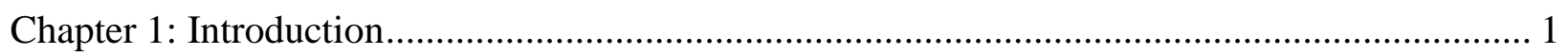

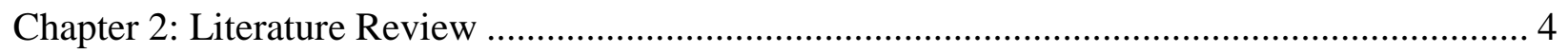

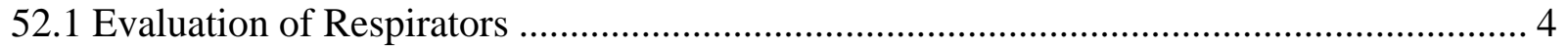

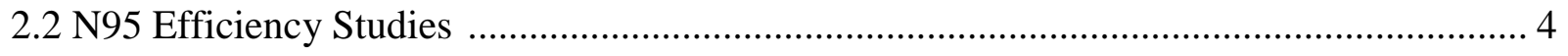

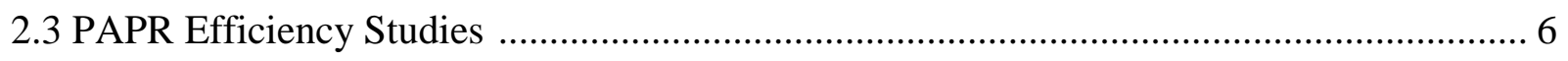

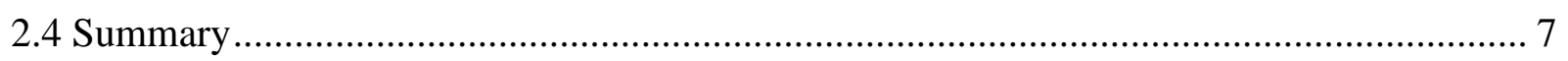

Chapter 3: Research Design and Methods .......................................................................... 8

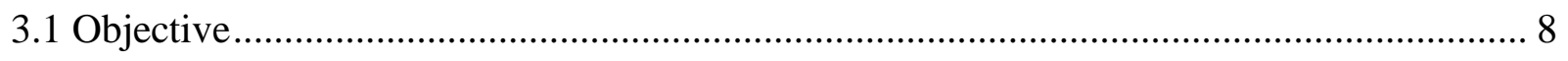

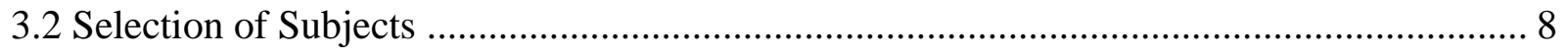

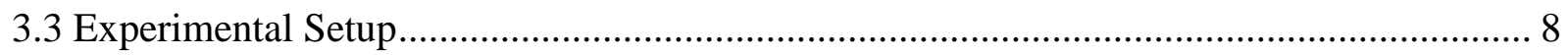

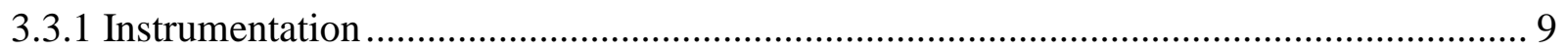

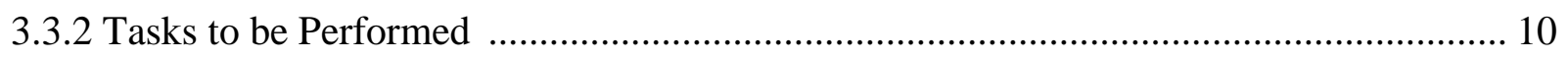

3.3.3 Parameters for Respirator Evaluation ............................................................. 11

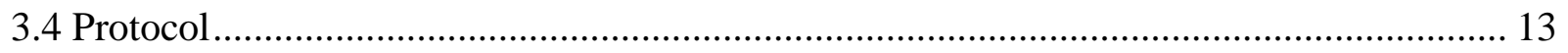

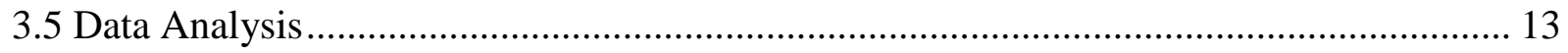

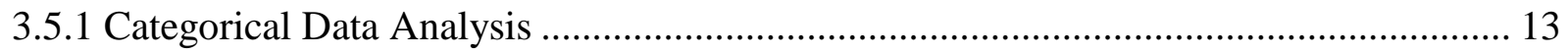

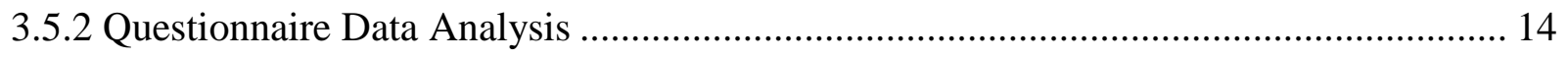

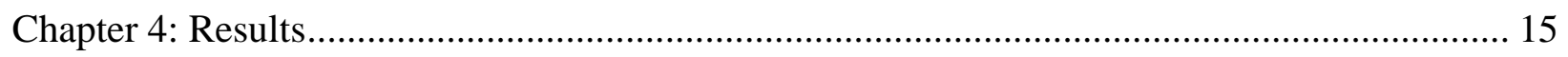

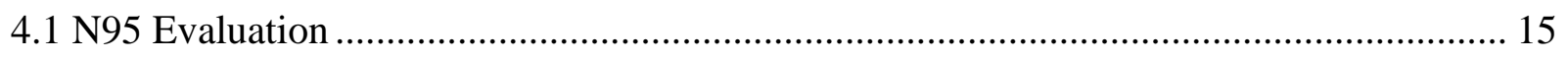

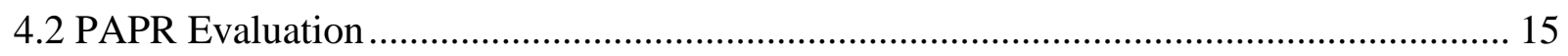

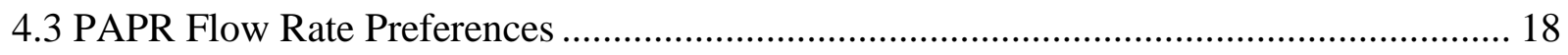

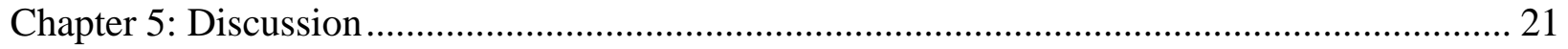

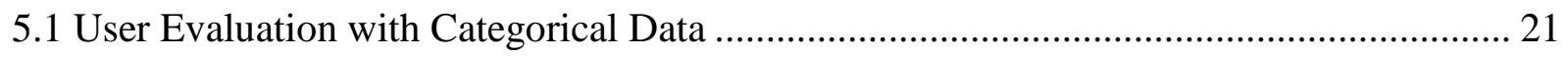

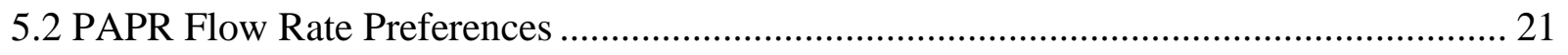


5.3 Comparing protection, acceptability, and percieved efficiency when conducting low-risk tasks................................................................................... 22

5.4 Comparing preference, acceptability, and effectiveness when conducting high-risk

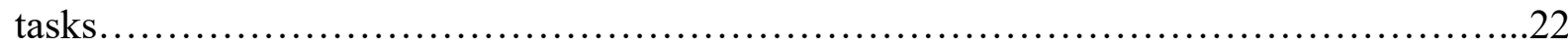

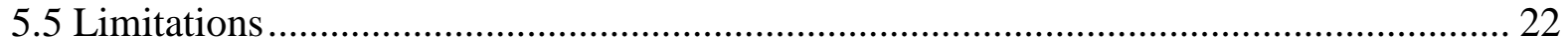

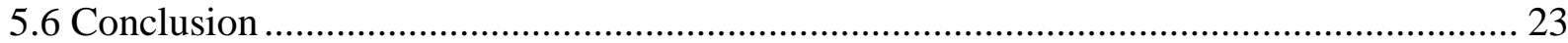

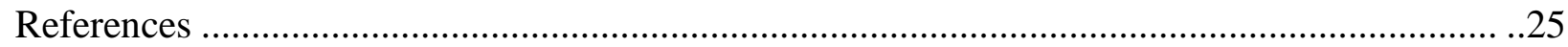

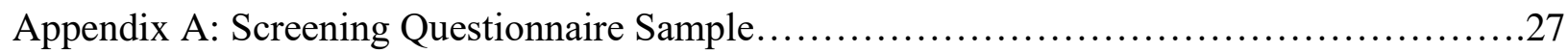

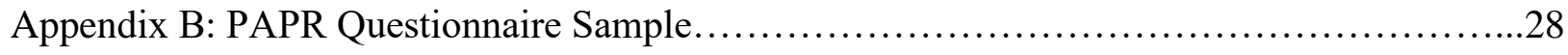

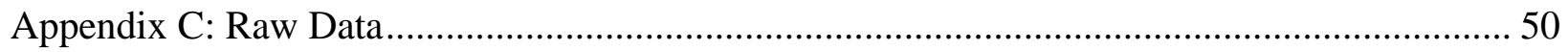

C.1 Evaluation Categories ……………………………................................................... 50 


\section{List of Figures}

Figure 1: N95 Mask............................................................

Figure 2: Types of PAPRs......................................................

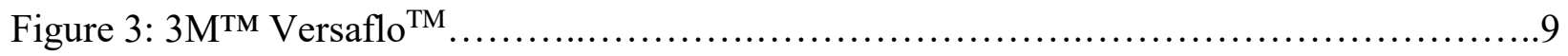

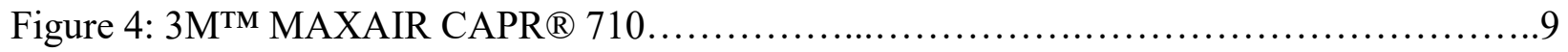

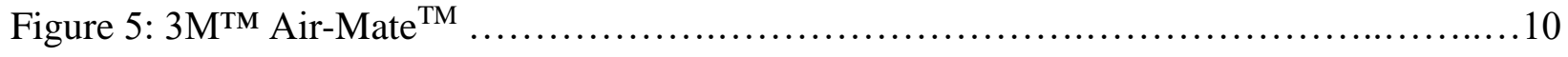




\section{List of Tables}

Table 1: List of Exercises to be completed when wearing each Respirator....................10

Table 2: Qualitative evaluation.................................................. 11

Table 3: Evaluation of flow rate and respirator preference............................... 12

Table 4: N95 FFR Descriptive results............................................ 15

Table 5: Versaflo Descriptive results............................................ 16

Table 6: Max-air Descriptive results............................................... 16

Table 7: Air-Mate Descriptive results............................................. 17

Table 8: Kruskal-Wallis Test Results for Categorical Data.............................18

Table 9: Comparing preference, acceptability, and effectiveness when evaluating flow

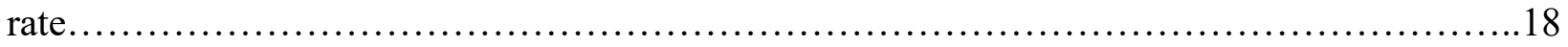

Table 10: Comparing preference, acceptability, and effectiveness when conducting low-risks

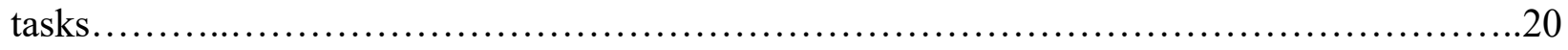

Table 11: Comparing preference, acceptability, and effectiveness when conducting high-risks

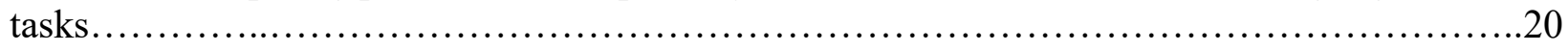




\section{List of Abbreviations}

ANOVA

APF

ATD

CA

CDC

CFM

CPR

EKG

EMT

EV

FDA

FFR

HCW

HSC

IV

METI

MUC

NIOSH

NPPTL

OSHA

PAPR

PEL
Analysis of Variance

Assigned Protection Factor

Aerosol Transmissible Diseases

Clinical Associate

Center for Disease Control

Cubic Feet per Meter

Cardiopulmonary Resuscitation

Electrocardiogram

Emergency Medical Technician

Exhalation Valve

Federal Drug Administration

Filtering Face Piece Respirators

Healthcare Worker

Health Sciences Center

Intravenous

Medical Education Technologies Inc.

Maximum Use Concentration

National Institute of Occupational Safety and Health

National Personal Protective Technology Laboratory

Occupational Safety and Health Administration

Powered Air-Purifying Respirator

Permissible Exposure Limit

viii 
PPE

$\mathrm{RN}$

SAR

SI

$\mathrm{SpO} 2$

STI

SWPF

TIL

WPF

WV STEPS

WVU
Personal Protective Equipment

Registered Nurse

Supplied Air Respirator

Speech Intelligibility

Blood Oxygen Level

Speech Transmission Index

Simulated Workplace Protection Factor

Total Inward Leakage

Workplace Protection Factor

West Virginia Simulation Training and Education for Patient Safety

West Virginia University 


\section{Chapter 1: Introduction}

Personal protective equipment, or PPE, is a necessity for those who work in the healthcare field. The typical PPE for healthcare workers includes gloves, goggles or glasses, a face shield, a gown, shoe covers, and a mask or respirator, all of which provide a barrier between the user and any infectious material. While the gloves, googles, and face shields provide external protection, it is the mask or respirators that will provide protection for a user's respiratory tract (Center for Disease Control, NA). Healthcare work environments pose hazards to workers because they presumably contain hazards such as aerosol transmissible diseases (ATDs).

The Occupational Safety and Health Administration (OSHA) requires all healthcare operations to provide employees protection against blood borne pathogens. In certain settings, engineering and administrative controls do not adequately protect users from airborne droplets, and therefore workers should use a form of respiratory protection. The most common form of respiratory protection is the N95 filtering face piece respirator (FFR), shown in figure 1.

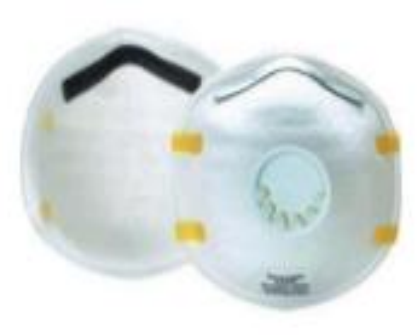

\section{Figure 1: N95 Mask, Left: No valves, Right: N95 with exhalation valve}

The most basic N95 respirators are designed to give the user a close facial fit and filtrate airborne particles. Some mask however, are equipped with exhalation valves to reduce heat build-up. The N stands for NOT resistant to oil, and are the only FFR's that have no service life. Other FFR's can be labeled R for resistant to oil, or P for protection against solid or liquid aerosols that may contain oil. The 95 means that this respirator blocks at least $95 \%$ of small $(0.3$ micron) test particles and are considered to exceed the filtration capabilities of the basic facemask. These mask are not compatible with children or people with facial hair. N95 mask are designed for use in industrial and health care settings. In the healthcare field specifically, the N95 respirators will be single-use and are considered a class II device that is regulated by the FDA (US Food and Drug Administration, 2018). 
While N95 mask provide protection against some airborne particles, they do not completely eliminate the risk of transmission of diseases. When a higher level of protection is required, then a worker should use a powered air-purifying respirator (PAPR). Defined by OSHA, a PAPR is a respirator that provides protection to the user by filtering out the airborne contaminants and using a battery-powered blower to supply the user with clean air via either a helmet, a tight-fitting respirator, or a loose-fitting hood (Board of Health Sciences Policy, 2015), shown in figure 2.

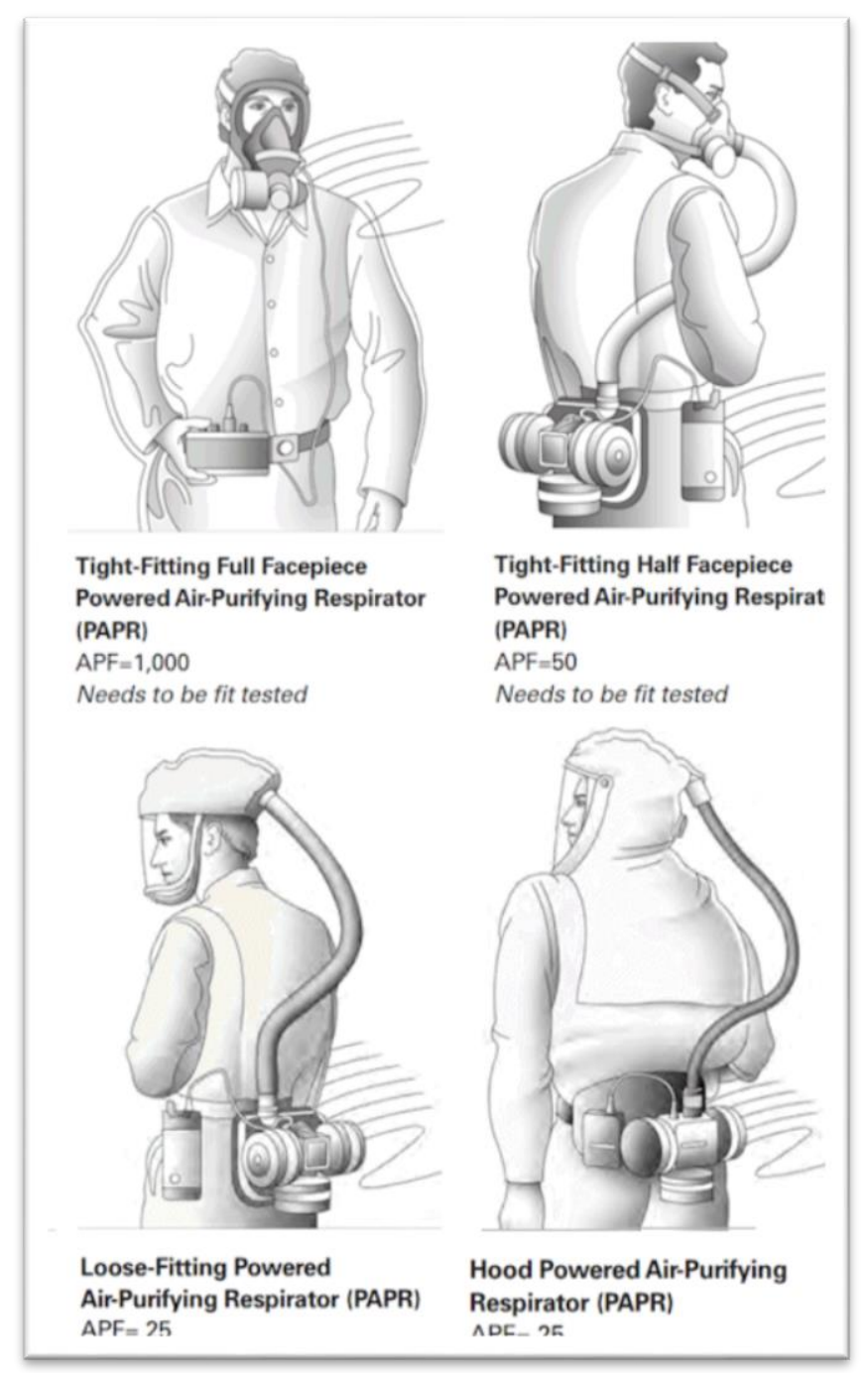

Figure 2: Types of PAPRs

Over the last decade, there have been several life-threatening disease outbreaks throughout the world. Healthcare workers are often the first responder's when it comes to controlling and maintaining an outbreak, since they are in close proximity with infected patients (Macintyre., Chughtai., Seale., Richards., \& Davidson, 2014). In the 2003 outbreak of Severe Acute Respiratory Syndrome (SARS), the Canadian outbreak alone resulted in more than 200 healthcare workers being infected, including three deaths. Likewise, the more recent 2014 Ebola 
outbreak resulted in 240 healthcare workers becoming infected and 120 workers died (Moore,

D., Yassi, A., \& Bryce, E. 2004).). With the increasing rate of disease, it is of upmost importance that healthcare workers wear proper respiratory protection. However, due to comfortability issues, wearing respirators for long periods of time can be difficult. 


\section{Chapter 2: Literature Review}

\section{1: Evaluation of Respirators}

There are several factors that determine the degree of protection afforded by a respirator and adequate protection is only achievable when they are selected for the proper tasks, are properly fitted for each user, and adequately maintained (OSHA7). One way to determine the efficiency of an FFR is to look at the assigned protection factor (APF), which is defined as the level of respiratory protection that a class of respirators can achieve when an employer properly follows a respiratory protection program. N95 masks have an assigned APF of 10, while PAPR's have an APF of 25 (OSHA8). Similarly, the maximum use concentration (MUC) can also be used to evaluate the respirator. The MUC is defined as the maximum concentration of a pollutant that an employee will be protected from when using that specific class of respirator. To determine the MUC of a given respirator, the OSHA permissible exposure limit (PEL) of the substance the employee will be exposed to is multiplied by the APF (Steelnack, 2007). Another evaluation factor used when determining the protection of a respirator is the total inward leakage (TIL). It is defined by the amount of contaminated air that leaks through a respirators face seal, valve, gasket, or by filter penetration (Baugh, 2015). Another important test used to determine the efficiency of FFR's is a fit-test, which will assess the type, size, and model of respirator needed for a specific user. The general fit testing procedures given by OSHA include several issues, such as making sure the user properly puts the respirator on, having the user asses comfort based on the position of mask on the nose, room for eye protection, room to talk, and position of mask on the face/cheek. The user must also determine adequacy of the respirator fit based on the strap tension, the fit across the nose bridge, proper size span from nose to chin, and tendency of respirator to move or slip. The user must also perform a seal check by using the positive and negative pressure seal checks given by OSHA, as well as perform a number of test exercises, including deep breathing and body movements (OSHA 29 CFR 1926.10.).

\subsection{N95 Efficiency Studies}

There have been several studies investigating the effectiveness and protection provided by $\mathrm{N} 95$ respirators. One previous study conducted aimed to determine the protection factors of N95 FFR's against particles that are similar in size to bacterial and viral particles, while also investigating the inhalation flow rate. The study measured the concentrations of particles outside and inside an N95 respirator using a sampling system connected to an electrical low pressure 
impactor that measures the aerodynamic size of particles ranging from 0.029-10.18 $\mu \mathrm{m}$.

Similarly, particles found in common diseases, such as SARS, H5N1, and B.anthracis range in sizes from $0.08-0.86 \mu \mathrm{m}$. Next, the protection factor was calculated by dividing the concentration of particles outside of the mask by the concentration of particles inside the mask. Results showed that the lowest protection factor provided by the N95 FFR occurred when particles were 0.08-0.2 $\mu \mathrm{m}$. Also, the following shows percentages for the four types of respirators tested, that had a protection factor less than 10: respirator A $(13.9 \%)$, respirator B $(63.9 \%)$, respirator C $(11.1 \%)$, and respirator D (22.2\%). Not only have N95 respirators demonstrated a lower efficiency then expected, studies have also investigated other avenues that deem the N95 FFR's unsuitable.

While the tolerability of an N95 FFR is subject to many variables, one of the major problems impacting the effectiveness of respirators is user discomfort. One of the most frequent complaints from N95 FFR users are related to the discomfort from facial and body heat. Thermal discomfort has also been shown to be a main reason for non-compliance when using the N95 FFR. One study focused on the effects of N95 FFR's on core and skin temperatures of users. Subjects were given two N95 FFR's, one with an exhalation valve (EV), and one without. Each subject performed a fit test and then walked on a treadmill for varying amounts of time, the core temperature was measured by an ingestible capsule and skin temperature was monitored with dermal sensors. The results showed minimal increases in core temperature and while skin temperatures of the cheek showed no significant increases at baseline, temperature increased as a function of time. Similarly, cheek temperatures fluctuated between FFR types. (Roberge, 2012).

Likewise, a similar study conducted required twelve subjects to wear three different types of respirators, including an N95 FFR, and two PAPR's. Each subject walked on a treadmill while undergoing physiological response monitoring. Results showed that when conducting low moderate work over a one hour period, there were no significant differences between the one FFR and the four PAPR's tested, in terms of heart rate, respiratory rate, oxygen saturation, transcutaneous CO2, exertion, facial heat, and body heat. However, respirator dead space heat and humidity as well as facial temperature, were significantly higher for N95 respirators, compared to the other PAPRs (Powell, Kim, \& Roberge, 2017). Despite these studies showing that facial and body heat do affect user comfort and acceptability of respirators, other studies have shown contrasting results.

Due to healthcare workers (HCW) needing to be able to communicate clearly with people, especially during public health emergencies, and with hospitals typically being loud environments, speech intelligibility (SI) can become a problem. During the SARS outbreak, 47\% of respondents to a health survey from hospital staff reported that wearing respiratory PPE was related to communication interference (Roberge, 2008). Research has shown that interference of FFR's with SI can lead users to be less compliant. Palmiero, Symons, Morgan, and Shaffer performed an assessment of SI while wearing protective facemasks using the Speech Transmission Index (STI). Results showed that when users wore an N95 FFR, their SI interference differed from controls by $17 \%$. The study also suggest that implementing engineering controls and improving designs could be the most effective way to improve SI in 
healthcare environments (Palmiero, Symons, Morgan, \& Shaffer, 2016). Similarly, another study showed that SI is decreased by at least $1-17 \%$ when wearing certain respirators when using the modified rhyme test, and that this is substantial enough to interfere with HCW job tasks (Radonovich Jr., Yanke, Cheng, \& Bender, 2009).

Another area that had been documented to interfere with respirator compliance and comfortability is the inducement of headaches after long-term use of FFR's. One study conducted by Lim, et al., set out to determine risk factors associated with the development and impact of headaches among HCW's. There were a total of 212 participants, with 79 of them reporting FFR associated headaches, and 26 of the 79 that reported headaches, also reported a frequency greater than six times a month (Lim, et al., 2006). Another study showed similar results, stating that wearing N95 masks for long durations may induce physiological stress and cause headaches. However, the study suggest this could be due to different temperatures and humidification between the inner and outer areas of the facemasks (Zhu, Lee, Wang, \& Lee., 2014).

\subsection{PAPR Efficiency Results}

While the number of studies investigating the efficiency and comfort factors is in an abundance for N95 respirators, research on PAPR's is less dense. However, there are studies showing that PAPR's provide adequate protection and have little discomfort issues among users.

One study conducted by Koivisto et al, (2015) assessed the program protection factor $(\mathrm{PPF})$, which is the protection a respirator provides in the context of a specific respirator program, provided by a loose-fitting PAPR. The study recruited three subjects and each were required to coat nanoparticles using a liquid flame spray process, while under a ventilation hood. The results showed that the respirators PPF exceeded more than $40 \times 10^{3}$ higher than the original APF of 25. A different study investigated the perceived protection of PAPR's during the SARS outbreak among healthcare workers. Subjects consisted of HCW's who have experience using PAPR's during the SARS outbreak. Results showed that $84 \%$ of those surveyed approved the PAPR for protection and preferred it over an N95 FFR when treating SARS patients (Khoo, Leng, Ibrahim, \& Lim, 2005). Similarly, another study measured the protection factors of PAPR's, as well as supplied-air respirators (SAR) with hoods and helmets. A total of twelve subjects performed a list of exercises while in a simulated workplace. Results showed that the majority of tested respirators provided a high degree of protection, with the SAR providing less protection than the PAPR's (Cohen, Hecker, Mattheis, Johnson, Biermann, \& Foote, 2010).

While PAPR's are considered more comfortable because they supply a cool airflow, reduce breathing effort, are light-weight, easy to use, don't require a fit test, and they cover your head, neck, there are some avenues that allow for discomfort. Some reported disadvantages of PAPR's are the weight of the battery or blower, the battery has to be charged, it can be very noisy, and that it can be awkward for certain tasks (Lenhart, Seitz, Trout, \& Bollinger, 2004). One study investigated thermal sensations and comfort of PAPR's. The study recruited twelve subjects and required them to wear five different types of respirators, which included an N95, one tight-fitting full face piece PAPR, two loose-fitting PAPR's, and one elastomeric PAPR. 
Each subject was required to walk on a treadmill for a total of one hour while having certain parameters measured. Results showed that the N95 FFR had a higher tympanic forehead temperature and a higher respirator dead space compared to the other PAPR'S. However, the perception of eye dryness was highest among the tight fitting PAPR, and the two loose-fitting PAPR's had a higher rate of facial heat, but this is thought to be due to exercise induced body heat (Powell, Kim, \& Roberge, 2017). A different study conducted by Johnson et al., (2007) evaluated sixteen subjects wearing a tight-fitting PAPR while exercising on a treadmill. The PAPR gave different flow rates ranging from 0\%-100\% of maximum blower capacity of 110 $\mathrm{L} / \mathrm{min}$. Results showed that as the flow rate reduced, performance time did as well. Also, differences in breathing comfort and facial thermal comfort were lower when the flow rate was lower, allowing researchers to conclude that higher flow rates allow users to have a better performance time, more facial cooling and respirator comfort (Johnson et al., 2007).

\subsection{Summary}

While there are a plethora of studies on $\mathrm{N} 95$ respirator use, and while there are several studies on PAPR's alone, few studies focus on both types of respirators and furthermore, there is a big literature gap comparing the use of FFR's to PAPR'S. With the amount of protection needed for HCW's when working with patients with serious diseases, and with the amount of increasing disease outbreaks over the years, having the best suitable respirators available to HCW's is vital. Therefore, the purpose of the following study was to evaluate user's perceived acceptability, preference, and effectiveness of four different respirators, and to compare them to each other. Specifically, compare the N95 FFR to the three PAPR's. 


\section{Chapter 3: Research Design and Methods}

\subsection{Objective}

This study, in conjunction with others, are part of the efforts of the National Personal Protective Technology Laboratory (NPPTL) at the CDC/NIOSH. The objective of this study was to assess HCW perceptions of comfort, suitability, and protective efficiency of different types of respirators, within a simulated healthcare setting by performing various tasks with varying degrees of risk. Respirators included: the 3M $\mathrm{M}^{\mathrm{TM}}$ particulate respirator 8210 N95 $160 \mathrm{EA}$, MAXAIR CAPR $® 710,3 \mathrm{M}^{\mathrm{TM}}$ Versaflo ${ }^{\mathrm{TM}} \mathrm{TR}-600-\mathrm{ECK}$ and the $3 \mathrm{M}^{\mathrm{TM}}$ Air-Mate ${ }^{\mathrm{TM}}$. The results of this study were used to compare the N95 FFR to the other three PAPR's in order to determine whether the N95 had similar ratings to the other PAPR's in terms of comfort, suitability, and protective efficiency. Also, we wanted to determine which respirator healthcare workers preferred to use overall.

\subsection{Selection of Subjects}

There were a total of 16 subjects recruited for this study and participation was voluntary. The purpose of this study, as well as the requirements for participation were emailed to HCW's in selected departments at Ruby Memorial Hospital in Morgantown, WV. Participants included both male (2) and females (14) that worked full-time as one of the following: a physician, registered nurse (RN), emergency medical technician (EMT), respiratory therapists, or clinical associate (CA). Requirements were as follows: between the ages of 18 to 55, non-smokers, no beard (only for N95), English speaking, not pregnant, do not have a systemic disease, and have been trained to use a PAPR. Those wishing to participate contacted Dr. Anna Allen (Clinical Professor, West Virginia University Hospital) where they completed a medical screening questionnaire (Appendix A), and were cleared for respirator use. Based on the medical screening questionnaire, the amount of experience given for each activity listed were totaled and subjects with the highest experience were selected first. Likewise, those with previous PAPR experience were invited to participate before those who had no experience.

\subsection{Experimental Setup}

In order to replicate a healthcare work environment as much as possible, subjects carried out the lists of tasks at the West Virginia Simulation Training and Education for Patient Safety (WVSTEPS) center at the campus of West Virginia University located in Morgantown, WV. Each simulation room consists of a METI human patient simulator, which is a life-like mannequin capable of producing breathes, blinking eyes, a pulse, a heartbeat, an airway that can mimic different levels of pulmonary obstruction, expires $\mathrm{CO}_{2}$, and can generate muscle twitches. The types of physiological situations needed for each unique learning situation or study can be manipulated in the computer room via the program called Laerdal Learning Application. In addition to the mannequin, the rooms are also equipped with monitoring devices, suction, stethoscopes, intravenous (IV) bags, needles, syringes, bed pans, EKG monitor, and an extra prosthetic arm equipped with fake blood. The same room and mannequin were used for all 16 
subjects, in which the mannequin is a male, 85 pounds, and 5.9 feet tall. The temperature was set at a constant $70^{\circ}$ Fahrenheit.

\subsubsection{Instrumentation}

A total of four respirators were used, one type of N95 FFR and three different types of PAPR's. All respirators used in this study are known to be used in healthcare settings.

1) $3 \mathrm{M}^{\mathrm{TM}}$ particulate respirator $8210 \mathrm{~N} 95160 \mathrm{EA}$, shown in figure 1, the system is a one-time use disposable mask that has a two-strap design with welded dual point attachment, a cushioned nose area, is lightweight, and has an advanced electrostatic media.

2) $3 \mathrm{M}^{\mathrm{TM}}$ Versaflo TM TR-600-ECK (loose-fitting), shown in figure 3, consists of a motor (TR602N), a battery (TR-971), easy clean belt (TR-627), airflow indicator (TR-971), a length adjusting breathing tube (BT-30), a chemical cartridge, and a filter. The standard airflow is 6.7 cfm and the system weights $4.5 \mathrm{lbs}$.

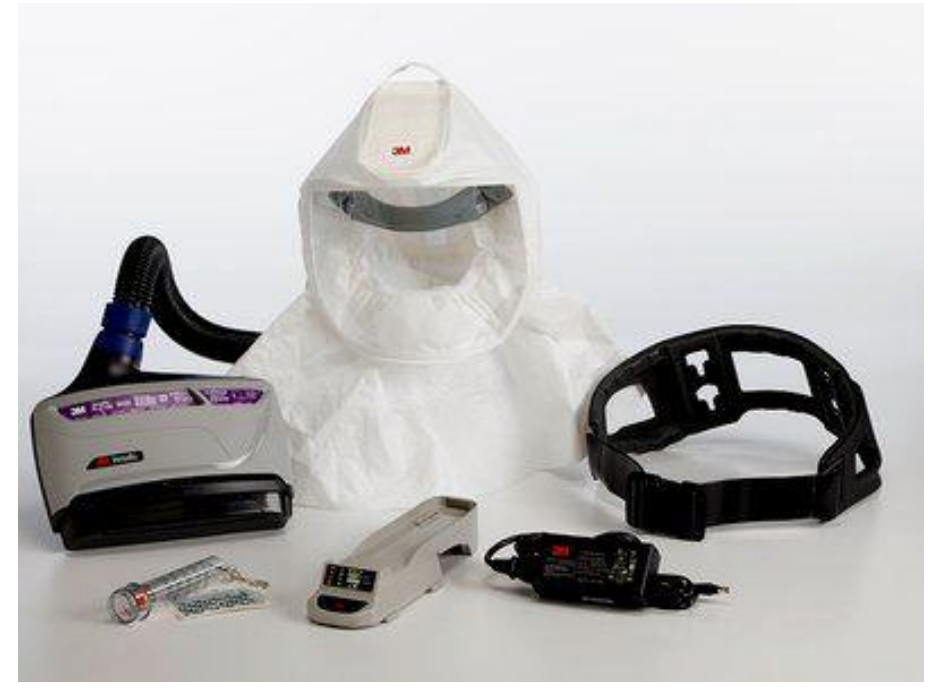

Figure 3: 3MTM Versaflo TM TR-600-ECK

3) MAXAIR CAPR® 710 System DLC-double shroud (loose-fitting), shown in figure 4, consists of a helmet (2065-03), battery (2000-36), charger (2600-01), belt (2000-76), and filter (2160-10). The airflow is set a $6 \mathrm{cfm}$ and the total weight is $2.5 \mathrm{lbs}$.

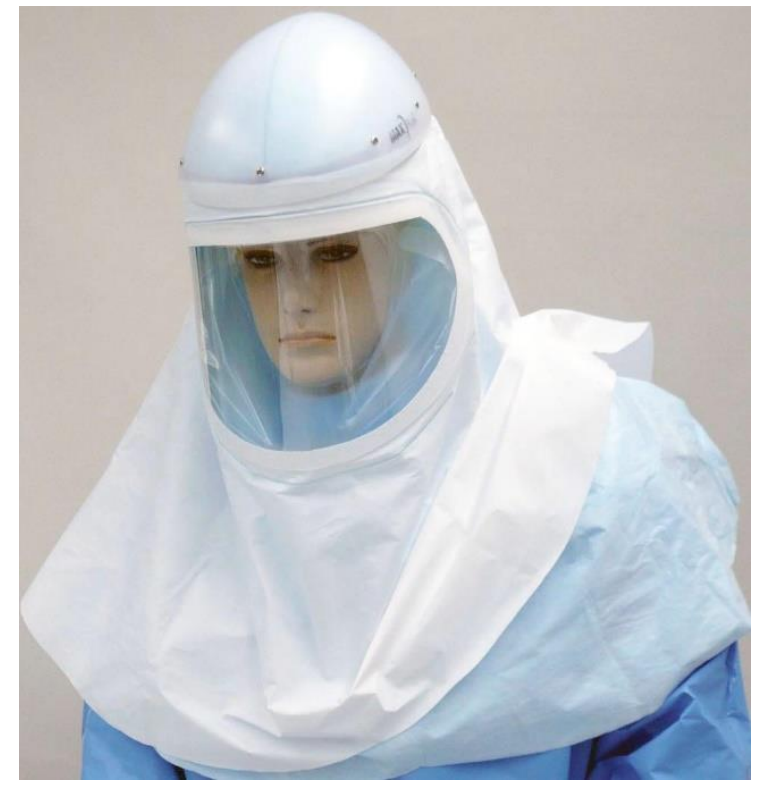


Figure 4: MAXAIR CAPR® 710

4) $3 \mathrm{M}^{\mathrm{TM}}$ Air-Mate ${ }^{\mathrm{TM}}$ Belt-Mounted High Efficiency PAPR, shown in figure 5, consists of a hood assembly (520-03-63R01), battery (007000015R01), high efficiency filter (451-02-01R0), nylon waist belt (021-14-00R01), and an airflow indicator (021-14-00R01). The airflow can be set at different levels and the total weight is $3 \mathrm{lbs}$.

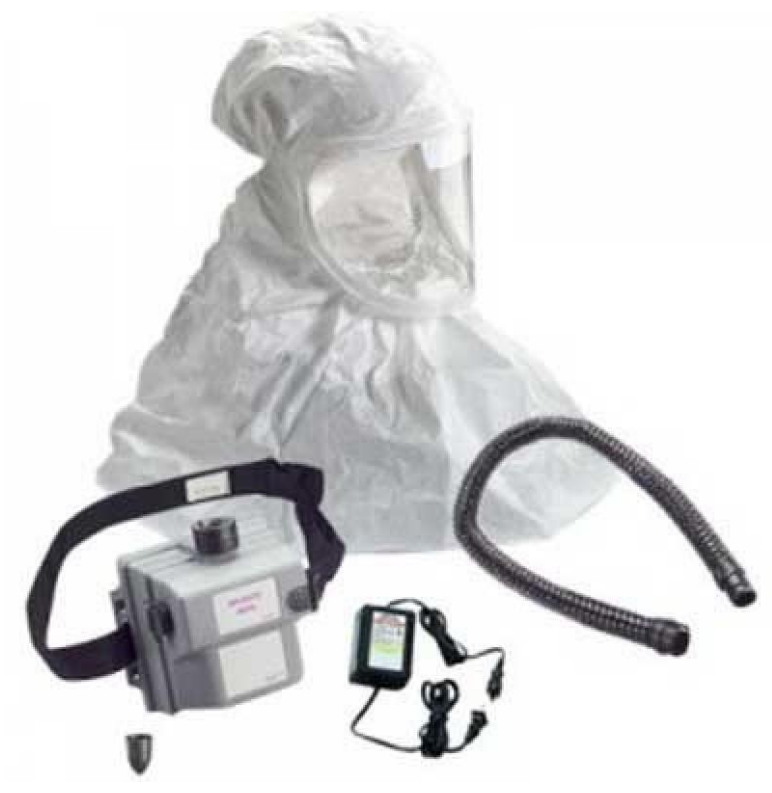

Figure 5: Air-Mate ${ }^{\mathrm{TM}}$

\subsubsection{Tasks to Be Performed}

In order for the subjects to be able to completely evaluate each respirator, a set of tasks that are common in the healthcare field were to be performed by each subject with all four respirators. After collaborating with the simulation lab personnel, a list comprised of twelve tasks was developed and are shown in figure 6, along with a description of each. It was estimated that the total time for each subject to complete all tasks and the questionnaire would take forty-five minutes to one hour. Although, most subjects completed all tasks within fifteen minutes, and along with the questionnaire the total time for each subject was around thirty minutes.

Table 1: List of Exercises to Be Completed When Wearing Each Respirator

\begin{tabular}{|c|c|}
\hline Tasks & Description \\
\hline Setting up bedding & $\begin{array}{l}\text { Fold/Position the sheets and blankets, make } \\
\text { sure patient has a pillow, organize room }\end{array}$ \\
\hline Positioning Patient & Adjust patient by lowering or raising the bed \\
\hline Asses Patient & $\begin{array}{c}\text { Use a stethoscope to asses patients } \\
\text { breathing/heartrate, take pulse, look at eyes, } \\
\text { nose, throat, and ears }\end{array}$ \\
\hline Hook up monitoring devices & Connect the electrodes to the patient \\
\hline Insert IV & $\begin{array}{l}\text { Identify vein, use Chloroprep to clean the } \\
\text { area, puncture vein using needle/ IV catheter }\end{array}$ \\
\hline Draw blood & $\begin{array}{l}\text { Hook syringe into catheter, pull back on } \\
\text { syringe to collect blood }\end{array}$ \\
\hline
\end{tabular}




\begin{tabular}{|c|c|}
\hline Start IV equipment & $\begin{array}{c}\text { Attach an IV bag to the IV catheter via tubing } \\
\text { and start the equipment }\end{array}$ \\
\hline Insert and set up Foley & $\begin{array}{c}\text { Clean area, lubricate tubing, insert tubing into } \\
\text { area, inflate the tubing via water-filled syringe }\end{array}$ \\
\hline Take urine sample & $\begin{array}{c}\text { Using the urine collection bag, collect a small } \\
\text { sample of urine }\end{array}$ \\
\hline Turn and bathe patient & $\begin{array}{c}\text { Remove patient's clothing, wash patient using } \\
\text { wash basing and washcloth. When finished, } \\
\text { redress patient with new gown }\end{array}$ \\
\hline Suctioning & $\begin{array}{c}\text { Turn on the suctioning machine, insert the } \\
\text { suction tube into the patients mouth, go to all } \\
\text { quadrants of the mouth }\end{array}$ \\
\hline Perform CPR & Perform at least two rounds of CPR \\
\hline
\end{tabular}

\subsubsection{Parameters for Respirator Evaluation}

After completion of all twelve tasks, each subject completed a questionnaire, which is shown in Appendix B. Qualitative evaluation of respirators was determined by choosing which number best expressed how the user felt about that specific parameter, these are shown in table 2 . Evaluation of flow rate and respirator preference when performing low-risk and high-risk tasks are shown in table 3 .

Table 2: Qualitative Evaluation

\begin{tabular}{|c|c|}
\hline Category & Scale \\
\hline General Comfort & $\begin{array}{l}\text { 1- Very poor } \\
\text { 2- Poor } \\
\text { 3- Acceptable } \\
\text { 4- Good } \\
\text { 5- Very good } \\
\text { 6- Excellent }\end{array}$ \\
\hline Inspiratory/Expiratory effort & $\begin{array}{l}\text { 1- Not noticeable } \\
7 \text { - Noticeable }\end{array}$ \\
\hline Overall breathing discomfort & $\begin{array}{l}\text { 1- Not at all } \\
\text { 2- Very slightly } \\
\text { 3- Slightly } \\
\text { 4- Somewhat high } \\
\text { 5- High } \\
\text { 6- Unbearable }\end{array}$ \\
\hline Facial and body heat & $\begin{array}{l}\text { 1- Not at all } \\
\text { 2- Very slightly } \\
\text { 3- Slightly } \\
\text { 4- Somewhat high } \\
\text { 5- High } \\
\text { 6- Unbearable }\end{array}$ \\
\hline Overall thermal comfort & $\begin{array}{l}1-\text { Coldest you've ever been } \\
5-\text { Neither cold nor hot } \\
10-\text { Hottest you've ever been }\end{array}$ \\
\hline Pressure or pain & $\begin{array}{l}\text { 1- Not at all } \\
\text { 2- Very slightly } \\
\text { 3- Slightly } \\
\text { 4- Somewhat high } \\
\text { 5- High } \\
\text { 6- Unbearable }\end{array}$ \\
\hline Eye discomfort & $\begin{array}{l}\text { 1- Not at all } \\
\text { 2- Very slightly }\end{array}$ \\
\hline
\end{tabular}




\begin{tabular}{|c|c|}
\hline & $\begin{array}{l}\text { 3- Slightly } \\
\text { 4- Somewhat high } \\
\text { 5- High } \\
\text { 6- Unbearable }\end{array}$ \\
\hline $\begin{array}{l}\text { Interference with wearing } \\
\text { glass/goggles/contact lenses }\end{array}$ & 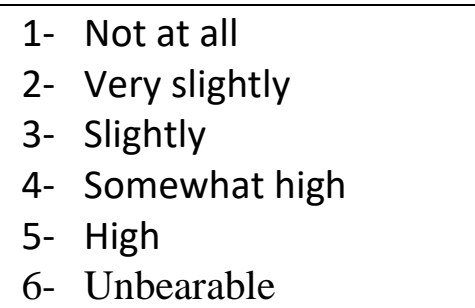 \\
\hline Clear line of vision & $\begin{array}{l}\text { 1- Very poor } \\
\text { 2- Poor } \\
\text { 3- Acceptable } \\
\text { 4- Good } \\
\text { 5- Very good } \\
\text { 6- Excellent } \\
\end{array}$ \\
\hline Difficulty putting on & $\begin{array}{l}\text { 1- Not at all } \\
\text { 2- Very slightly } \\
\text { 3- Slightly } \\
\text { 4- Somewhat high } \\
\text { 5- High } \\
\text { 6- Unbearable }\end{array}$ \\
\hline Difficulty to operate & $\begin{array}{l}\text { 1- } \text { Not at all } \\
\text { 2- Very slightly } \\
\text { 3- Slightly } \\
\text { 4- Somewhat high } \\
\text { 5- } \text { High } \\
\text { 6- Unbearable }\end{array}$ \\
\hline Mechanical interference with duties & $\begin{array}{l}\text { 1- Not at all } \\
\text { 2- Very slightly } \\
\text { 3- Slightly } \\
\text { 4- Somewhat high } \\
\text { 5- High } \\
\text { 6- Unbearable }\end{array}$ \\
\hline Exertion & $\begin{array}{l}6-\text { No exertion at all } \\
20-\text { Maximal exertion }\end{array}$ \\
\hline $\begin{array}{l}\text { Hours you could wear this respirator } \\
\text { continuously? }\end{array}$ & Written response \\
\hline $\begin{array}{c}\text { Perceived efficiency against biological } \\
\text { hazards }\end{array}$ & $\begin{array}{l}\text { 1- Not at all } \\
\text { 2- Very slightly } \\
\text { 3- Slightly } \\
\text { 4- Somewhat High } \\
\text { 5- High } \\
\text { 6- } \text { Complete }\end{array}$ \\
\hline Overall Assessment & $\begin{array}{l}\text { 1- Not at all } \\
\text { 2- Very slightly } \\
\text { 3- Slightly } \\
\text { 4- Somewhat high } \\
\text { 5- } \text { High } \\
\text { 6- Unbearable }\end{array}$ \\
\hline
\end{tabular}

Table 3: Evaluation of Flow Rate and Respirator Preference

\begin{tabular}{|c|c|}
\hline Question & Type of response \\
\hline $\begin{array}{c}\text { When performing the following tasks (deemed low risks), do you } \\
\text { prefer a lower flow rate for the following PAPR? }\end{array}$ & Yes or No for each respirator \\
\hline
\end{tabular}




\begin{tabular}{|c|c|}
\hline $\begin{array}{c}\text { When performing the following tasks (deemed low risks), do you } \\
\text { think a lower flow rate is more acceptable? }\end{array}$ & Yes or No for each respirator \\
\hline $\begin{array}{c}\text { When performing the following tasks (deemed low risks), do you } \\
\text { think a lower flow rate is more effective? }\end{array}$ & Yes or No for each respirator \\
\hline $\begin{array}{c}\text { When performing the following tasks (deemed low risks), which type } \\
\text { of the following 5 respirators do you prefer to use? }\end{array}$ & Yes or No for each respirator \\
\hline $\begin{array}{c}\text { When performing the following tasks (deemed low risks), which type } \\
\text { of the following 5 respirators do you think is more acceptable? }\end{array}$ & Yes or No for each respirator \\
\hline $\begin{array}{c}\text { When performing the following tasks (deemed low risks), which type } \\
\text { of the following 5 respirators do you think is more effective? }\end{array}$ & Yes or No for each respirator \\
\hline $\begin{array}{c}\text { When performing the following tasks (deemed high risks), which type } \\
\text { of the following 5 respirators do you prefer to use? }\end{array}$ & Yes or No for each respirator \\
\hline $\begin{array}{c}\text { When performing the following tasks (deemed high risks), which } \\
\text { type of the following 5 respirators do you think is more } \\
\text { acceptable? }\end{array}$ & Yes or No for each respirator \\
\hline $\begin{array}{c}\text { When performing the following tasks (deemed high risks), which } \\
\text { type of the following 5 respirators do you think is more effective? }\end{array}$ & Yes or No for each respirator \\
\hline Nausea & Yes or No for each respirator \\
\hline Dizziness of difficult concentrating & Yes or No for each respirator \\
\hline Unusual smell or odor & Yes or No for each respirator \\
\hline Eye irritation & Yes or No for each respirator \\
\hline
\end{tabular}

\subsection{Protocol}

Once subjects arrived at the WV STEPS center, they were directed to the donning room where they would complete a signed consent. The risk associated with the experiment, as well as an overview of what was expected was given to the subject. Next, the subject was taken down the hall to the simulation room and a brief orientation of the room and materials were given to the subject to ensure familiarity when performing the list of tasks.

Upon returning to the donning room, subjects would then put on the first respirator assigned. In order to reduce bias, the order in which the subjects wore the types of respirators were randomized using Microsoft Excel. Subjects were taken to the simulation room with their respirator on and running. Once beginning the tasks, a timer was set to twenty minutes. There was always at least one investigator in the room with the subject to oversee, sometimes there were extra investigators present.

Once all tasks were completed and the room was put back in order, subjects returned to the donning room to remove all equipment. As subjects answered the questionnaire, the investigator would clean all materials before returning them to their proper area. The subject would then continue through the same steps for the next three respirators. Upon completion of the study, subjects were compensated and given receipts for tax purposes.

\subsection{Data Analysis}

All questionnaire data was transferred to Microsoft Excel and separated into two categories: categorical and questionnaire. The categorical data was analyzed using SAS JMP software, while the questionnaire data was analyzed using Microsoft Excel.

\subsubsection{Categorical Data Analysis}

There were a total of sixteen categories, each having four groups, one for each respirator.

Due to the data being ordinal, a normal distribution couldn't be assumed and non-parametric test 
were performed using SAS JMP software. To compare the three different PAPR's to the N95 FFR, non-parametric test, specifically a Kruskal-Wallis test was performed. An alpha level was set at 0.05 , as well as 0.1 for comparison efforts.

\subsubsection{Questionnaire Data Analysis}

There were a total of thirteen questions, all of which consisted of only yes or no responses. The questions compared preference, acceptability, and effectiveness for flow rates, high-risk tasks, and low-risk tasks. Also included were symptoms such as nausea, dizziness, unusual smell or odor, and eye irritation. Using Microsoft excel, percentages were calculated for all answers. 


\section{Chapter 4: Results}

\subsection{N95 Evaluation}

Each of the sixteen subjects evaluated the N95 FFR for sixteen categories and the summary is shown in Table 4. The mean, standard deviation, minimum and maximum values were calculated for each category.

Table 4: N95 FFR Descriptive Results

\begin{tabular}{|c|c|c|c|c|}
\hline Category & Mean & $\begin{array}{l}\text { Standard } \\
\text { Deviation }\end{array}$ & Minimum & Maximum \\
\hline General Comfort & 2.58 & 1.177 & 1 & 5 \\
\hline $\begin{array}{l}\text { Inspiratory/Expiratory } \\
\text { effort }\end{array}$ & 3.52 & 1.589 & 1 & 7 \\
\hline $\begin{array}{l}\text { Overall breathing } \\
\text { discomfort }\end{array}$ & 3.16 & 1.293 & 1 & 5 \\
\hline Facial and body heat & 3.84 & 1.293 & 1 & 6 \\
\hline Overall thermal comfort & 6.55 & 1.410 & 3 & 10 \\
\hline Pressure or pain & 2.81 & 1.223 & 1 & 5 \\
\hline Eye discomfort & 1.71 & 1.160 & 1 & 4 \\
\hline $\begin{array}{l}\text { Interference with } \\
\text { wearing } \\
\text { glasses/goggles/contacts }\end{array}$ & 2.52 & 1.951 & 1 & 8 \\
\hline Clear line of visions & 4.65 & 1.226 & 2 & 6 \\
\hline Difficulty putting on & 1.74 & 1.064 & 1 & 5 \\
\hline Difficulty to operate & 1.16 & 0.454 & 1 & 3 \\
\hline $\begin{array}{l}\text { Mechanical interference } \\
\text { with duties }\end{array}$ & 1.39 & 0.803 & 1 & 4 \\
\hline Exertion & 9.65 & 2.961 & 6 & 16 \\
\hline $\begin{array}{l}\text { How many hours could } \\
\text { you wear this respirator } \\
\text { continuously? }\end{array}$ & 1.79 & 2.232 & 0 & 12 \\
\hline $\begin{array}{l}\text { Perceived efficiency } \\
\text { against biological } \\
\text { hazards }\end{array}$ & 3.52 & 1.338 & 1 & 6 \\
\hline Overall assessment & 3.87 & 1.176 & 1 & 6 \\
\hline
\end{tabular}

Please note that all categories were scaled from one to six, with one being the best possible choice. There are a few exceptions, general comfort and clear line of vision were scaled from one to six, with one being the worst possible choice. Overall thermal comfort was scaled from one to ten with one being the coldest and ten being the hottest. Exertion was scaled from six to twenty, with six being the best choice.

\subsection{PAPR Evaluation}

Each of the sixteen subjects evaluated all three PAPR'S for each of the sixteen categories and the summary for each PAPR are shown in Tables 5-7. The mean, standard deviation, minimum and maximum values were calculated for each category. The same scales were identical to those used for the N95 FFR. 
Table 5: Versaflo Descriptive Results

\begin{tabular}{|l|c|c|c|c|}
\hline \multicolumn{1}{|c|}{ Category } & Mean & $\begin{array}{c}\text { Standard } \\
\text { Deviation }\end{array}$ & Minimum & Maximum \\
\hline General Comfort & 2.94 & 1.209 & 1 & 5 \\
\hline $\begin{array}{l}\text { Inspiratory/Expiratory } \\
\text { effort }\end{array}$ & 2.32 & 1.351 & 1 & 5 \\
\hline $\begin{array}{l}\text { Overall breathing } \\
\text { discomfort }\end{array}$ & 2.06 & 1.237 & 1 & 5 \\
\hline Facial and body heat & 2.65 & 1.496 & 1 & 6 \\
\hline Overall thermal comfort & 5.45 & 1.895 & 1 & 10 \\
\hline Pressure or pain & 2.00 & 1.317 & 1 & 5 \\
\hline Eye discomfort & 1.39 & 0.667 & 1 & 3 \\
\hline $\begin{array}{l}\text { Interference with } \\
\text { wearing } \\
\text { glasses/goggles/contacts }\end{array}$ & 1.96 & 1.186 & 1 & 5 \\
\hline Clear line of visions & 3.48 & 0.926 & 2 & 6 \\
\hline Difficulty putting on & 3.23 & 1.055 & 1 & 5 \\
\hline Difficulty to operate & 2.55 & 1.434 & 1 & 6 \\
\hline $\begin{array}{l}\text { Mechanical interference } \\
\text { with duties }\end{array}$ & 3.29 & 1.321 & 1 & 6 \\
\hline Exertion & 9.48 & 3.395 & 6 & 6 \\
\hline $\begin{array}{l}\text { How many hours could } \\
\text { you wear this respirator } \\
\text { continuously? }\end{array}$ & 1.99 & 1.567 & 0.2 & 17 \\
\hline $\begin{array}{l}\text { Perceived efficiency } \\
\text { against biological } \\
\text { hazards }\end{array}$ & 3.94 & 1.263 & 2 & 1 \\
\hline Overall assessment & 3.48 & 1.546 & & 6 \\
\hline
\end{tabular}

Table 6: Max-air Descriptive Results

\begin{tabular}{|l|c|c|c|c|}
\hline \multicolumn{1}{|c|}{ Category } & Mean & $\begin{array}{c}\text { Standard } \\
\text { Deviation }\end{array}$ & Minimum & Maximum \\
\hline General Comfort & 3.74 & 1.094 & 2 & 6 \\
\hline $\begin{array}{l}\text { Inspiratory/Expiratory } \\
\text { effort }\end{array}$ & 1.58 & 0.848 & 1 & 5 \\
\hline $\begin{array}{l}\text { Overall breathing } \\
\text { discomfort }\end{array}$ & 1.29 & 0.529 & 1 & 3 \\
\hline Facial and body heat & 2.19 & 0.980 & 1 & 5 \\
\hline Overall thermal comfort & 5.39 & 1.256 & 1 & 8 \\
\hline Pressure or pain & 1.94 & 1.153 & 1 & 5 \\
\hline Eye discomfort & 1.45 & 0.995 & 1 & 5 \\
\hline $\begin{array}{l}\text { Interference with } \\
\text { wearing } \\
\text { glasses/goggles/contacts }\end{array}$ & 2.00 & 1.382 & 1 & 5 \\
\hline Clear line of visions & 4.03 & 1.354 & 1 & 6 \\
\hline Difficulty putting on & 2.35 & 0.985 & 1 & 5 \\
\hline Difficulty to operate & 1.65 & 0.755 & 1 & 3 \\
\hline $\begin{array}{l}\text { Mechanical interference } \\
\text { with duties }\end{array}$ & 2.68 & 1.045 & 1 & 5 \\
\hline Exertion & 8.13 & 1.910 & 6 & 13 \\
\hline
\end{tabular}




\begin{tabular}{|l|c|c|c|c|}
\hline $\begin{array}{l}\text { How many hours could } \\
\text { you wear this respirator } \\
\text { continuously? }\end{array}$ & 2.47 & 1.751 & 0.15 & 8 \\
\hline $\begin{array}{l}\text { Perceived efficiency } \\
\text { against biological } \\
\text { hazards }\end{array}$ & 3.42 & 1.409 & 1 & 6 \\
\hline Overall assessment & 2.84 & 1.068 & 1 & 5 \\
\hline
\end{tabular}

Table 7: Air-Mate Descriptive Results

\begin{tabular}{|c|c|c|c|c|}
\hline Category & Mean & $\begin{array}{l}\text { Standard } \\
\text { Deviation }\end{array}$ & Minimum & Maximum \\
\hline General Comfort & 3.77 & 1.055 & 1 & 6 \\
\hline $\begin{array}{l}\text { Inspiratory/Expiratory } \\
\text { effort }\end{array}$ & 1.90 & 0.908 & 1 & 4 \\
\hline $\begin{array}{l}\text { Overall breathing } \\
\text { discomfort }\end{array}$ & 1.61 & 0.844 & 1 & 4 \\
\hline Facial and body heat & 2.00 & 1.000 & 1 & 4 \\
\hline Overall thermal comfort & 4.87 & 0.991 & 2 & 7 \\
\hline Pressure or pain & 1.58 & 0.720 & 1 & 3 \\
\hline Eye discomfort & 1.29 & 0.783 & 1 & 4 \\
\hline $\begin{array}{l}\text { Interference with } \\
\text { wearing } \\
\text { glasses/goggles/contacts }\end{array}$ & 1.87 & 1.140 & 1 & 4 \\
\hline Clear line of visions & 4.03 & 1.140 & 2 & 6 \\
\hline Difficulty putting on & 2.77 & 0.990 & 1 & 5 \\
\hline Difficulty to operate & 2.13 & 0.885 & 1 & 4 \\
\hline $\begin{array}{l}\text { Mechanical interference } \\
\text { with duties }\end{array}$ & 2.52 & 1.151 & 1 & 5 \\
\hline Exertion & 8.39 & 2.552 & 6 & 17 \\
\hline $\begin{array}{l}\text { How many hours could } \\
\text { you wear this respirator } \\
\text { continuously? }\end{array}$ & 2.08 & 1.106 & 0.2 & 4 \\
\hline $\begin{array}{l}\text { Perceived efficiency } \\
\text { against biological } \\
\text { hazards }\end{array}$ & 3.68 & 1.249 & 1 & 6 \\
\hline Overall assessment & 2.97 & 1.140 & 1 & 6 \\
\hline
\end{tabular}

All data was reformatted for further analysis using SAS JMP statistical software and nonparametric test were conducted. The $\alpha$-level for the Kruskal-Wallis test were set at 0.1 and 0.5 , and all categories from the questionnaire were included. The results from the test are shown below in table 8 . 
Table 8: Kruskal-Wallis Test Results for Categorical Data

\begin{tabular}{|c|c|c|c|c|}
\hline Category & $\begin{array}{c}\text { Chi-squared } \\
\text { Result }\end{array}$ & p-value & $\begin{array}{l}\text { Hypothesis results } \\
(\alpha<0.05)\end{array}$ & $\begin{array}{c}\text { Hypothesis } \\
\text { results }(\alpha<0.1)\end{array}$ \\
\hline General Comfort & 11.39092 & 0.0442 & $\begin{array}{l}\text { Reject null } \\
(\mathrm{p}<0.05)\end{array}$ & $\begin{array}{l}\text { Reject null } \\
(p<0.1)\end{array}$ \\
\hline $\begin{array}{l}\text { Inspiratory/expiratory } \\
\text { effort }\end{array}$ & 0.071705 & 0.9994 & $\begin{array}{l}\text { Fail to reject null } \\
(p>0.05)\end{array}$ & $\begin{array}{l}\text { Fail to reject null } \\
(p>0.1)\end{array}$ \\
\hline $\begin{array}{l}\text { Overall breathing } \\
\text { discomfort }\end{array}$ & 0.261475 & 0.9922 & $\begin{array}{l}\text { Fail to reject null } \\
(\mathrm{p}>0.05)\end{array}$ & $\begin{array}{l}\text { Fail to reject null } \\
(\mathrm{p}>0.1)\end{array}$ \\
\hline Facial and body heat & 4.312439 & 0.3654 & $\begin{array}{l}\text { Fail to reject null } \\
(\mathrm{p}>0.05)\end{array}$ & $\begin{array}{l}\text { Fail to reject null } \\
(\mathrm{p}>0.1)\end{array}$ \\
\hline Overall thermal comfort & 10.24852 & 0.1146 & $\begin{array}{l}\text { Fail to reject null } \\
(\mathrm{p}>0.05)\end{array}$ & $\begin{array}{l}\text { Fail to reject null } \\
(\mathrm{p}>0.1)\end{array}$ \\
\hline Pressure or pain & 8.303087 & 0.0401 & $\begin{array}{l}\text { Reject null } \\
(\mathrm{p}<0.05)\end{array}$ & $\begin{array}{l}\text { Reject null } \\
(p<0.1)\end{array}$ \\
\hline Eye discomfort & 0.573388 & 0.9025 & $\begin{array}{l}\text { Fail to reject null } \\
(p>0.05)\end{array}$ & $\begin{array}{l}\text { Fail to reject null } \\
(\mathrm{p}>0.1)\end{array}$ \\
\hline $\begin{array}{l}\text { Interference with wearing } \\
\text { glasses/goggles/contacts }\end{array}$ & 25.781 & 0.0011 & $\begin{array}{l}\text { Reject null } \\
(\mathrm{p}<0.05)\end{array}$ & $\begin{array}{l}\text { Reject null } \\
(p<0.1)\end{array}$ \\
\hline Clear line of vision & 8.862527 & 0.0646 & $\begin{array}{l}\text { Fail to reject null } \\
(\mathrm{p}>0.05)\end{array}$ & $\begin{array}{l}\text { Reject null } \\
(\mathrm{p}<0.1)\end{array}$ \\
\hline Difficulty putting on & 3.16049 & 0.5313 & $\begin{array}{l}\text { Fail to reject null } \\
(\mathrm{p}>0.05)\end{array}$ & $\begin{array}{l}\text { Fail to reject null } \\
(\mathrm{p}>0.1)\end{array}$ \\
\hline Difficult to operate & 1.739704 & 0.7835 & $\begin{array}{l}\text { Fail to reject null } \\
(\mathrm{p}>0.05)\end{array}$ & $\begin{array}{l}\text { Fail to reject null } \\
(p>0.1)\end{array}$ \\
\hline $\begin{array}{l}\text { Mechanical interference } \\
\text { with duties }\end{array}$ & 3.336675 & 0.5031 & $\begin{array}{l}\text { Fail to reject null } \\
(\mathrm{p}>0.05)\end{array}$ & $\begin{array}{l}\text { Fail to reject null } \\
(\mathrm{p}>0.1)\end{array}$ \\
\hline Exertion & 8.591805 & 0.2833 & $\begin{array}{l}\text { Fail to reject null } \\
(\mathrm{p}>0.05)\end{array}$ & $\begin{array}{l}\text { Fail to reject null } \\
(\mathrm{p}>0.1)\end{array}$ \\
\hline $\begin{array}{l}\text { How many hours could you } \\
\text { wear this respirator } \\
\text { continuously? }\end{array}$ & 28.2711 & 0.0009 & $\begin{array}{l}\text { Reject null } \\
(\mathrm{p}<0.05)\end{array}$ & $\begin{array}{l}\text { Reject null } \\
(\mathrm{p}<0.1)\end{array}$ \\
\hline $\begin{array}{l}\text { Perceived efficiency } \\
\text { against biological hazards }\end{array}$ & 9.641867 & 0.0860 & $\begin{array}{l}\text { Fail to reject null } \\
(p>0.05)\end{array}$ & $\begin{array}{l}\text { Reject null } \\
(\mathrm{p}<0.1)\end{array}$ \\
\hline Overall assessment & 2.326425 & 0.6760 & $\begin{array}{l}\text { Fail to reject null } \\
(\mathrm{p}>0.05)\end{array}$ & $\begin{array}{l}\text { Fail to reject null } \\
(\mathrm{p}>0.1)\end{array}$ \\
\hline
\end{tabular}

When $\alpha<0.05$, the Kruskal-Wallis test showed that a total of four categories showed significant results. Those categories include: general comfort, pressure or pain, interference with wearing glasses/goggles/contacts, and how many hours could you wear this respirator continuously. When $\alpha<0.1$, six categories showed significant results including the same four as when $\alpha<0.05$, along with the categories for clear line of vision and perceived efficiency against biological hazards.

\subsection{PAPR Flow Rate Preference}

This set of data evaluated the preference, acceptability, and effectiveness of flow rates, as well as respirator preference when conducting high-risk and low-risk tasks. Also, symptoms of nausea, dizziness, odor, and eye irritation were also evaluated. The results are shown as frequency percentages in tables 9-11.

Table 9: Comparing preference, acceptability, and effectiveness of flow rates

\begin{tabular}{|c|c|c|c|}
\hline Question & Respirator & Yes & No \\
\hline When performing the & N95 & NA & NA \\
\cline { 2 - 4 } following tasks & Versaflo & $50 \%$ & $50 \%$ \\
\cline { 2 - 4 } (deemed low risks), & MAXAIR & $38 \%$ & $63 \%$ \\
\cline { 2 - 4 } do you prefer a lower & AIRMATE & $50 \%$ & $50 \%$ \\
\hline
\end{tabular}




\begin{tabular}{|c|c|c|c|}
\hline $\begin{array}{c}\text { flow rate for the } \\
\text { following? }\end{array}$ & & & \\
\hline \multirow{4}{*}{$\begin{array}{l}\text { When performing the } \\
\text { following tasks } \\
\text { (deemed low risks), } \\
\text { do you think a lower } \\
\text { flow rate is more } \\
\text { acceptable? }\end{array}$} & N95 & NA & NA \\
\hline & Versaflo & $50 \%$ & $50 \%$ \\
\hline & MAXAIR & $50 \%$ & $50 \%$ \\
\hline & AIRMATE & $63 \%$ & $38 \%$ \\
\hline \multirow{4}{*}{$\begin{array}{l}\text { When performing the } \\
\text { following tasks } \\
\text { (deemed low risks), } \\
\text { do you think a lower } \\
\text { flow rate is more } \\
\text { effective? }\end{array}$} & N95 & NA & NA \\
\hline & Versaflo & $38 \%$ & $63 \%$ \\
\hline & MAXAIR & $38 \%$ & $63 \%$ \\
\hline & AIRMATE & $50 \%$ & $50 \%$ \\
\hline
\end{tabular}

The N95 couldn't be evaluated in terms of flow rate due to being an FFR not a PAPR. While results for Versaflo and MAXAIR were each $50 \%$ for both yes and no answers, in terms of preferring the PAPR have a lower flow rate, most of the subjects $(63 \%)$ preferred that the MAXAIR did not have a lower flow rate. Similarly, the Versaflo and MAXAIR were each 50\% for both yes and no answers in terms of whether a lower flow rate is more acceptable. However, the majority $(63 \%)$ of subjects thought it was acceptable for a lower flow rate for the AIRMATE PAPR. In addition, the AIRMATE has a $50 \%$ yes or no answer rate when determining whether a lower flow rate is more effective. However, $63 \%$ of subjects for both the Versaflo and the MAXAIR thought a lower flow rate would not be more effective.

Table 10: Comparing preference, acceptability, and effectiveness when conducting low-risks tasks

\begin{tabular}{|c|c|c|}
\hline Question & Respirator & Percentage \\
\hline \multirow{4}{*}{$\begin{array}{l}\text { When performing the } \\
\text { following tasks } \\
\text { (deemed low risks), } \\
\text { which type of the } \\
\text { following } 5 \\
\text { respirators do you } \\
\text { prefer to use? }\end{array}$} & N95 & $25 \%$ \\
\hline & Versaflo & $0 \%$ \\
\hline & MAXAIR & $38 \%$ \\
\hline & AIRMATE & $25 \%$ \\
\hline \multirow{5}{*}{$\begin{array}{l}\text { When performing the } \\
\text { following tasks } \\
\text { (deemed low risks), } \\
\text { which type of the } \\
\text { following } 5 \\
\text { respirators do you } \\
\text { think is more } \\
\text { acceptable? }\end{array}$} & N95 & $50 \%$ \\
\hline & Versaflo & $0 \%$ \\
\hline & MAXAIR & $25 \%$ \\
\hline & AIRMATE & $25 \%$ \\
\hline & N95 & $25 \%$ \\
\hline
\end{tabular}




\begin{tabular}{|c|c|c|}
\hline When performing the & Versaflo & $0 \%$ \\
following tasks \\
(deemed low risks), & MAXAIR & $63 \%$ \\
\cline { 2 - 3 } $\begin{array}{c}\text { which type of the } \\
\text { following 5 } \\
\text { respirators do you } \\
\text { think is more } \\
\text { effective? }\end{array}$ & AIRMATE & $13 \%$ \\
& & \\
\hline
\end{tabular}

When determining which respirator the subjects preferred to use when conducting lowrisk tasks, most subjects chose MAXAIR (38\%), while 0\% chose AIRMATE. When determining which respirator was more acceptable, subjects preferred the N95 FFR (50\%), followed by both MAXAIR and AIRMATE at $25 \%$. In addition, when determining which respirator was most effective, subjects preferred MAXAIR 63\% more than other respirators, while no subjects (0\%) chose Versaflo.

Table 11: Comparing preference, acceptability, and effectiveness when conducting high-risks tasks

\begin{tabular}{|c|c|c|}
\hline Question & Respirator & Percentage \\
\hline \multirow{4}{*}{$\begin{array}{l}\text { When performing the } \\
\text { following tasks } \\
\text { (deemed high risks), } \\
\text { which type of the } \\
\text { following } 5 \\
\text { respirators do you } \\
\text { prefer to use? }\end{array}$} & N95 & $13 \%$ \\
\hline & Versaflo & $0 \%$ \\
\hline & MAXAIR & $50 \%$ \\
\hline & AIRMATE & $38 \%$ \\
\hline \multirow{4}{*}{$\begin{array}{l}\text { When performing the } \\
\text { following tasks } \\
\text { (deemed high risks), } \\
\text { which type of the } \\
\text { following } 5 \\
\text { respirators do you } \\
\text { think is more } \\
\text { acceptable? }\end{array}$} & N95 & $13 \%$ \\
\hline & Versa flow & $13 \%$ \\
\hline & MAXAIR & $50 \%$ \\
\hline & AIRMATE & $25 \%$ \\
\hline \multirow{4}{*}{$\begin{array}{l}\text { When performing the } \\
\text { following tasks } \\
\text { (deemed high risks), } \\
\text { which type of the } \\
\text { following } 5 \\
\text { respirators do you } \\
\text { think is more } \\
\text { effective? }\end{array}$} & N95 & $13 \%$ \\
\hline & Versa flow & $13 \%$ \\
\hline & MAXAIR & $63 \%$ \\
\hline & AIRMATE & $13 \%$ \\
\hline
\end{tabular}

Similar to the low-risk tasks data, when determining which respirator the subjects preferred to use when conducting high-risk tasks, most subjects chose MAXAIR (50\%), while $0 \%$ chose Versaflo. In terms of acceptability, most subjects preferred MAXAIR (50\%), followed by AIRMATE (25\%). Additionally, when evaluating the most effective respirator, subjects preferred MAXAIR (63\%), while the other three respirators were all 13\%. 


\section{Chapter 5: Discussion}

\subsection{User evaluation with Categorical Data}

Data from the current study indicate that, when comparing the means of the N95 FFR mask to each of the three PAPR's individually, all three PAPR's were rated higher in eleven of the sixteen categories. The five categories in which the N95 was more preferred over the PAPR's were as follows: clear line of vision, difficulty to put on, difficulty to operate, mechanical interference with duties, and perceived efficiency against biological hazards. This is likely due to the fact of the simple design of the N95 when compared to an entire PAPR setup with the hood, belt, battery, etc. It was anticipated that the N95 would rank less than all PAPR's in terms of protection against biological hazards due to the fact that the PAPR equipment covers more of the body and supplies air, however it was not rated lowest in this category. It is worth mentioning that the only PAPR of the three that was rated lower than the N95 in terms of perceived efficiency against biological hazards was MAXAIR, the other two PAPR's were preferred over the N95 in this category. It is also worth mentioning the results of the PAPR's themselves within each category. for the following six categories: inspiratory/expiratory, overall breathing, exertion, how many hours could you wear this respirator continuously, and overall assessment, MAXAIR was rated best followed by Airmate and then Versaflo. When evaluating the following categories: general comfort, facial and body heat, overall thermal comfort, and pressure or pain, Airmate was rated best followed by MAXAIR and then Versaflo. The last three remaining categories all had a mixture of results. For eye discomfort, Airmate was most preferred to not interfere, followed by Versaflo and then MAXAIR. When looking at whether the PAPR's interfered with wearing goggles/glasses/contacts, Airmate had no interference, followed by Versaflo, and then MAXAIR showing the most interference. Lastly, in terms of perceived efficiency of protection against biological hazards, Versaflo was thought to be more protective, followed by Airmate and MAXAIR.

When evaluating the results of the Kruskal-Wallis test, when $\alpha<0.05$, only four of sixteen categories showed significant results when comparing the results of all three PAPRS combined to the N95. These four categories were general comfort, pressure or pain, interference with wearing glasses/goggles/contacts, and how many hours could you wear this respirator continuously. Also, when $\alpha<0.1,6$ of the sixteen categories were significant, the same four as previously mentioned, along with clear line of vision and perceived efficiency against biological hazards. This is most likely due to the variation in the different types of PAPR's, since we combined the data from all three PAPR's. For instance, MAXAIR and AIRMATE were each preferred in almost all categories over the Versaflo.

\subsection{PAPR Flow Rate Preference}

When asked whether subjects preferred a lower flow rate for any of the PAPR's, results were mixed, with 50\% answering yes and 50\% answering no. The only results differing from the median was MAXAIR, in which 63\% answered no that they did not prefer a lower flow rate. When asked if subjects thought a lower flow rate is more acceptable for any of the PAPR's, 
results were similar to the first question, in which $50 \%$ for both yes and no. However, Airmate showed $63 \%$ did actually agree that a lower flow rate would be more acceptable. Also, when asked if a lower flow rate would be more effective, while Airmate showed the trending 50\% results, both the MAXAIR and Versa flow showed that $38 \%$ of subjects did think a lower flow rate would be more effective. With most results showing that the majority of subjects were mixed about how they felt towards having a lower flow rate, this could be due to the subjects not having a chance to really adjust or choose which flow rate they used prior to conducting the tasks. Also, subjects could be confused about the question or wording of the question, as well as not have been thinking about the flow rate while conducting tasks.

\subsection{Comparing preference, acceptability, and effectiveness when conducting low-risk tasks}

When asked which type of respirator out of the four used that the subject would prefer, most subjects (38\%) preferred MAXAIR, while none preferred Versaflo. This could be due to MAXAIR being lightweight (2.5 lbs.), and loose-fitting, Also, a lot of subjects expressed that the helmet fit more comfortably than others because it was more cushioning and the straps distributed the weight of the helmet better. Also, the Versaflo could have been the least preferred to use due to it being the heaviest at $4.5 \mathrm{lbs}$. When asked which respirator subjects thought was more acceptable, half (50\%) answered that the N95 was most acceptable. This could be due the lightweight, easy to use, and easy to put on aspects of the mask. Again, Versaflo rated the least with $0 \%$ thinking it is acceptable over the other respirators. When subjects answered which respirator they thought was most effective, more than half (63\%) answered that they thought MAXAIR was most effective. This was followed by the N95, then Airmate, and lastly with Versaflo. This could be due to the fact that the MAXAIR is very comfortable, has a fully covering helmet, and is lightweight.

\subsection{Comparing preference, acceptability, and effectiveness when conducting high-risk tasks}

When asked which respirator the subjects preferred to use when conducting high-risk tasks, 50\% preferred MAXAIR, followed by 38\% suggesting Airmate, with $13 \%$ answering N95, and with $0 \%$ preferring Versaflo. These results could be due to the fact that The MAXAIR and Airmate are the lighter weight PAPR's and are more comfortable then Versaflo. Also, users could prefer to use the N95 over the Versaflo because it is easy to use, easy to put on, and lighter. When asked which respirator was most acceptable, MAXAIR was most acceptable at

$50 \%$, followed by Airmate at 25\%. Both the N95 and Versaflo showed $13 \%$ of subjects thinking it was acceptable. Similar to previous results, subjects tend to like the lighter weight designs of MAXAIR and Airmate. When asked which respirator was most effective, as with the other trends, MAXAIR was rated highest at $63 \%$, however, all other three respirators were equally rated at $13 \%$ each. This could be due to subjects thinking more about the hazards of high-risk tasks and wanting more protection that is durable but yet comfortable.

\subsection{Limitations}

There were a few limitations to this study, with the most simplistic being that the sample size was rather small. Increasing the sample size to perhaps 50 subjects would allow for more 
variability and could show more significant results. Also, within the small sample size, there were only two groups of healthcare workers, it would be nice to have some physician's to add to the diversity of the group and for comparisons reasons. Typically, registered nurses have the most experience with PAPR's due to them having the most direct contact with patients so adding more physicians could change the results.

Another limitation could be that due to some of the subjects having been working in the field for a long period of time, they were so accustomed to their duties that they finished all tasks very quickly compared to some other subjects. By adding more time that each subject would wear each respirator, either by adding more or different types of tasks, or by collecting data on multiple occasions, would allow for more accurate feel of what the respirator would be like during the real healthcare setting.

Another possible limitation could have been that subjects could have been confused or not careful when answering the ratings for each category on the questionnaire because the rating scale changed several times as you go from category to category. However, all subjects were told to ask questions if they did not understand a question.

\subsection{Conclusion}

In the study conducted by Lee, Grinshpun, \& Reponen (2008), their results showed than an N95 mask is not considered adequate protection for particles found in common diseases. Also, OSHA states that while an N95 mask does protect against airborne particles, when a higher degree of protection is required, a PAPR is best. However, in comparison to these previous studies, the current study showed that while the Airmate and Versaflo were perceived as having a higher protection against biological hazards than the N95, the MAXAIR PAPR was actually thought to be slightly less protective than the N95.

With facial and body heat discomfort being reported as one of the main reasons for noncompliance with respirators, it's important to investigate the ratings of this category. Studies conducted by Roberge (2012) showed that the temperature of the facial skin while wearing an N95 masks increased significantly over time. Likewise, another study conducted showed that in comparison to respirators, N95 masks are shown to have higher facial temperatures (Powell, Kim, \&Roberge, 2017). Results of this study showed that, similar to other studies, PAPR's were rated to have less thermal discomfort in comparison to the N95 FFR.

Another commonly reported issue with respirators was SI, with the total SI decreasing up to $17 \%$. When asking subjects for the current study about their interference with their duties however, the N95 had less interference with duties than all PAPR's. This could be due to the fact that the question the subjects answered on the questionnaire asked if there was any mechanical interference with duties, as opposed to specifically asking if SI was effected. Also, the sounds from the batteries on the PAPR's could have played a role in the reduction on SI. Similar to some of the reported disadvantages of PAPR's, such as a heavy battery, noise from blower, and having to charge a battery, several subjects in the current study expressed similar views (Lenhart, Seitz, Trout, \& Bollinger, 2004). 
Overall, out of the four respirators used, subjects only preferred the N95 FFR over the PAPR's in five of sixteen categories. With these categories being clear line of vision, difficulty putting on, difficulty operating, and mechanical interference with duties are all sensible due to the fact that the N95 is the smallest, lightest, and easiest to use. However, when it came to the other eleven tasks, PAPR's were more preferred. More specifically, MAXAIR was typically the most preferred PAPR, followed by Airmate and then Versaflo. These results could be due to subjects being familiar with MAXAIR, it being the lighter weight PAPR, also the helmet design was liked among subjects. The results of the current study can be used to help fill the literature gap on respirator use and help manufacturers design respirators to be better fit for HCW's or users. Further research should aim to address some of the following aspects of respirator use: whether respirators play a role on physiological aspects such as heartbeat, body temperature, breathing, etc. Also, further studies should use other means of measurement than solely a questionnaire, such as using a thermometer to measure temperature or implementing other devices to measure heartbeat, blood pressure, number of breaths, etc. These types of studies can only further the efforts of providing the best and most adequate protection for healthcare workers, especially in the face of a disease outbreak. 


\section{References}

1. Baugh, L. (2015). Total Inward Leakage Testing for Respirators. International Safety Equipment Assocaiton. Retrieved from https://safetyequipment.org/knowledge-center-items/total-inwardleakage-testing-for-respirators/

2. Board on Health Sciences Policy; Institute of Medicine. (2015). The Use and Effectiveness of Powered Air Purifying Respirators in Health Care: Workshop Summary. National Academic Press. Retrieved from https://www.ncbi.nlm.nih.gov/books/NBK294223/

3. Center for disease control. (NA). Guidance for selection and use of personal protective equipment (PPE) in healthcare settings. [Powerpoint slides]. Retrieved from https://www.cdc.gov/HAI/pdfs/ppe/PPEslides6-29-04.pdf

4. Cohen, H.J., Hecker, L.H., Mattheis, D.K., Johnson, J.S., Biermann, A.H., \& Foote, K.L. (2010). Simulated Workplace Protection Factor Study of Powered Air-Purifying and Supplied Air Respirators. American Industrial Hygiene Assocation, 62(5), 595-604.

5. Johnson, A.T., Mackey, K.R., Scott, W.H., Koh, F.C., Chiou, K.Y.H., \& Phelps, S.J. (2007). Exercise Performance While Wearing a Tight-Fitting Powered Air Purifying Respirator with Limited Flow. Journal of Occupational and Environmental Hygiene, 2(7), 368-373.

6. Khoo, K.L., Leng, P.H., Ibrahim, I.B., * Lim, T.K. (2005). The changing face of healthcare worker perceptions on powered air-purifying respirators during the SARS outbreak. Respirology, 10(1), 107-110.

7. Koivisto, A.J., Aromaa, M., Koponen, I.K., Fransman, W., Jensen, K.A., Makela, J.M., \& Hameri, K.J. (2015). Workplace performance of a loose-fitting powered air purifying respirator during nanoparticle synthesis. Journal of Nanoparticle Research, 17, 177.

8. Lee, S., Grinshpun, S.A., \& Reponen, T. (2008). Respiratory Performance Offered by N95 Respirators and Surgical Masks: Human Subject Evaluation with $\mathrm{NaCl}$ Aerosol Representing Bacterial and Viral Particle Size Range, The Annals of Occupational Hygiene, 52(3), 177-185. https://doi.org/10.1093/annhyg/men005

9. Lenhart, S.W., Seitz, T., Trout, D., \& Bollinger, N. (2004). Issues Affecting Respirator Selection for Workers Exposed to Infectious Aerosols: Emphasis on Healthcare Settings. Applied Biosafety, 9(1), 20-36.

10. Lim, E.C.H., Seet, R.C.S., Lee, K.H., Wilder-Smith, E.P.V., Chuah, B.Y.S., Ong, B.K.C. (2006). Headaches and the N95 face-mask amongst healthcare providers. Acta Neurologica Scandinavica, 113(3), 199-202.

11. Macintyre, C.R., Chughtai, A.A., Seale, H., Richards, G.A., \& Davidson, P.M. (2014).

Respiratory protection for healthcare workers treating Ebola virus disease (EVD): Are facemasks sufficient to meet occupational health and safety obligations?. International Journal of Nursing Studies, 51(11), 1421-1426. Retrieved from https://www.sciencedirect.com/science/article/pii/S002074891400234X

12. Moore, D., Yassi, A., \& Bryce, E. (2004). Protecting the Faces of Health Care Workers: Knowledge Gaps and Research Priorities for Effective Protection Against OccupationallyAcquired Respiratory Infectious Diseases. The Change Foundation. Retrieved from 
http://www.phsa.ca/Documents/Occupational-Health-

Safety/ReportProtectingtheFacesofHealthcareWorkers.pdf

13. Palmiero, A. J., Symons, D., Morgan, J. W., \& Shaffer, R. E. (2016). Speech intelligibility assessment of protective facemasks and air-purifying respirators. Journal of occupational and environmental hygiene, 13(12), 960-968.

14. Powell, J. B., Kim, J. H., \& Roberge, R. J. (2017). Powered air-purifying respirator use in healthcare: Effects on thermal sensations and comfort. Journal of occupational and environmental hygiene, 14(12), 947-954.

15. Radonovich Jr., L.J., Yanke, R., Cheng, J., \& Bender, B. (2009). Diminished Speech Intelligibility Associated with Certain Types of Respirators Worn by Healthcare Workers. Journal of Occupational and Environmental Hygiene, 7(1), 63-70.

16. Roberge, R.J. (2008). Effect of surgical masks worn concurrently over N95 filtering facepiece respirators: extended service life versus increases user burden. Journal of Public Health Management, 14(2), 19-26. doi: 10.1097/01.PHH.0000311904.41691.fd.

17. Roberge, R., Benson, S., \& Kim, J. (2012). Thermal Burden of N95 Filtering Facepiece Respirators, The Annals of Occupational Hygiene, 56(7), 808-814. https://doi.org/10.1093/annhyg/mes001

18. US Food \& Drug Administration (FDA). (2018). Masks and N95 Respirators. Retrieved fromhttps://www.fda.gov/medicaldevices/productsandmedicalprocedures/generalhospitaldevices andsupplies/personalprotectiveequipment/ucm055977.htm

19. Occupational Safety and Health Administration. NIOSH Guide to the Selection and Use of Particulate Respirators Certified Under 42 CFR 84 [DHHS (NIOSH) Publication No. 96-101]. Retrieved from https://www.osha.gov/dts/osta/otm/otm_viii/otm_viii_2.html

20. Occupational Safety and Health Administration. 63 FR 1152, Jan. 8, 1998; 63 FR 20098, April 23, 1998; 71 FR 16672, April 3, 2006; 71 FR 50187, August 24, 2006; 73 FR 75584, Dec. 12, 2008; 76 FR 33606, June 8, 2011]. Retrieved from https://www.osha.gov/lawsregs/regulations/standardnumber/1910/1910.134

21. Occupational Safety and Health Administration. 29 CFR 1926.10.

22. Steelnack, J.(2007). Assigned Protection Factor (APF) Table Added to OSHA's Respiratory Protection https://www.aiha.org/aihce07/handouts/rt243steelnack.pdfStandard 29 CFR 1910.134. [Powerpoint presentation].

23. Zhu, J.H., Lee, S.J., Wang, D.Y., \& Lee, H. (2014). Effects of long-duration wearing of N95 respirator and surgical facemask: a pilot study. Journal of Lung, Pulmonary, \& Respiratory Research, 1(4), 97-100. 


\section{Appendix A: Screening QuestionnaireAnalysis of User}

\section{Preference with N95 and Powered Air-Purifying Respirators in a}

\section{healthcare work environment}

\begin{tabular}{|c|c|c|c|}
\hline \multirow{2}{*}{\multicolumn{4}{|c|}{ PLEASE PRINT AND COMPLEIE ALL ENIRIES }} \\
\hline \multicolumn{3}{|c|}{ NAME (LAST -- FIRST -- MIDDLE INITIAL) } & \\
\hline SEX (M or F) & Phone Number & Email Address & YEARS OF WORK EXPERIENCE \\
\hline \multicolumn{2}{|c|}{$\begin{array}{l}\text { Have you used a PAPR before? (Yes or } \\
\text { No) }\end{array}$} & \multicolumn{2}{|c|}{$\begin{array}{l}\text { If you have used a PAPR before, what specific activities do you use it } \\
\text { for? }\end{array}$} \\
\hline \multicolumn{4}{|c|}{ Which hospital unit/department are you from? Please briefly describe your daily work activities. } \\
\hline \multicolumn{4}{|c|}{$\begin{array}{l}\text { What is your experience with the following activities? (1: very experienced, 2: somewhat experienced; } 3 \text { : } \\
\text { inexperienced) }\end{array}$} \\
\hline \multicolumn{4}{|c|}{ Set up bedding/room } \\
\hline \multicolumn{4}{|c|}{ Position patient } \\
\hline \multicolumn{4}{|c|}{ Assess patient } \\
\hline \multicolumn{4}{|c|}{ Hook up monitoring devices } \\
\hline \multicolumn{4}{|c|}{ Insert IV } \\
\hline \multicolumn{4}{|c|}{ Draw blood } \\
\hline \multicolumn{4}{|c|}{ Start IV equipment } \\
\hline \multicolumn{4}{|c|}{ Insert and set up foley } \\
\hline \multicolumn{4}{|c|}{ Take urine sample } \\
\hline \multicolumn{4}{|c|}{ Turn and bathe patient } \\
\hline \multicolumn{4}{|c|}{ Suctioning } \\
\hline & Im CPR & & \\
\hline
\end{tabular}




\section{Appendix B: User Evaluation QuestionnaireAnalysis of}

\section{User Preference with N95 and Powered Air-Purifying}

\section{Respirators in a healthcare work environment}

Date:

Study ID: 002

BASIC INFOMATION

PLEASE PRINT AND COMPLETE ALL ENTRIES

NAME (LAST -- FIRST -- MIDDLE INITIAL) JOB TITLE

SEX AGE (Years) Weight (Ib.)

List of Tested Respirators:

\begin{tabular}{|l|c|c|c|c|}
\hline \multicolumn{1}{|c|}{ Respirator 1 } & Respirator 2 & Respirator 3 & Respirator 4 & Respirator 5 \\
\hline \multicolumn{1}{|c|}{ Versflow } & Koken & AIR MATE & MAX AIR & N95 \\
\hline Time & & & & \\
Start: & & & & \\
Stop: & & & & \\
\hline
\end{tabular}

\section{List of Exercises}

Set up bedding/room

Position patient

Assess patient

Hook up monitoring devices

Insert IV

Draw blood 
Start IV equipment

Insert and set up foley

Take urine sample

Turn and bathe patient

Suctioning

Perform CPR 
Study ID:

Place a circle next to the following scales corresponding to your evaluation of each respirator.

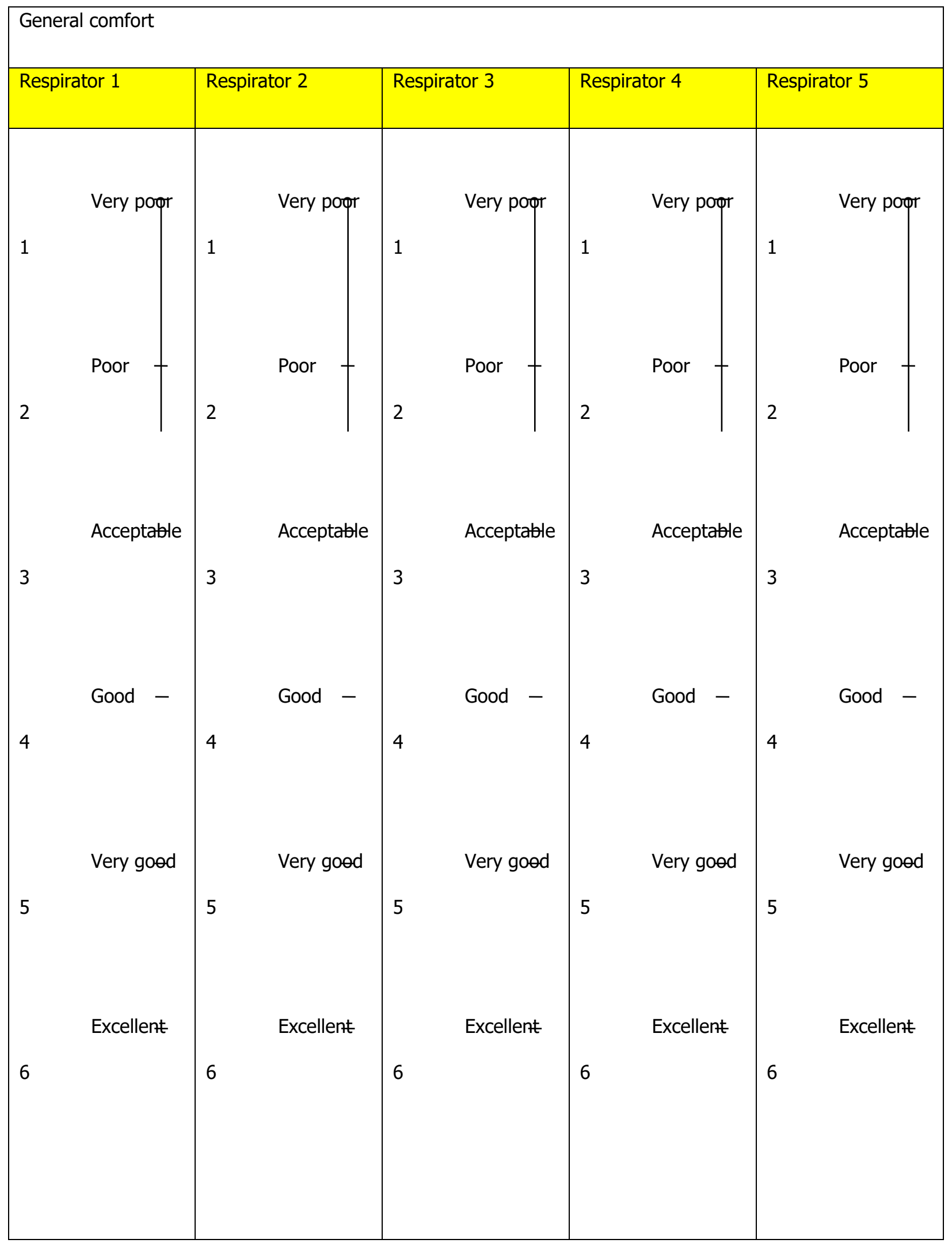

\begin{tabular}{|c|c|c|c|c|}
\hline \multicolumn{5}{|c|}{ Inspiratory/expiratory effort } \\
\hline Respirator & Respirator & Respirator & Respirator & Respirator \\
\hline 1 & 2 & 3 & 4 & 5 \\
\hline
\end{tabular}




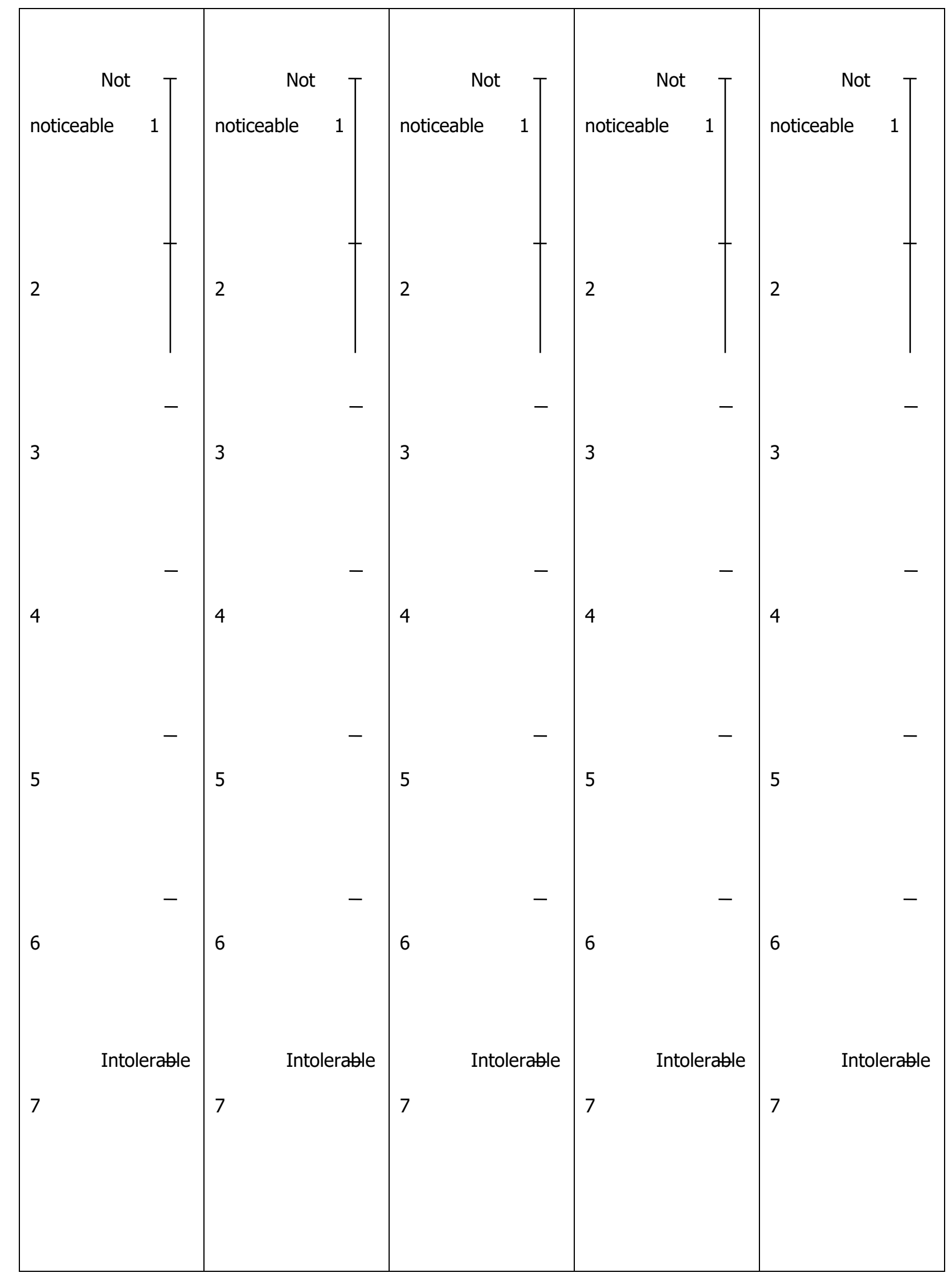

Overall breathing discomfort

\begin{tabular}{|l|l|l|l|l|}
\hline Respirator 1 & Respirator 2 & Respirator 3 & Respirator 4 & Respirator 5 \\
\hline & & & & \\
\hline
\end{tabular}




\begin{tabular}{|c|c|c|c|c|c|c|c|c|c|}
\hline & Not at aft & \multicolumn{2}{|r|}{ Not at aft } & \multicolumn{2}{|r|}{ Not at aft } & \multicolumn{2}{|r|}{ Not at aft } & \multicolumn{2}{|r|}{ Not at aft } \\
\hline 1 & & 1 & & 1 & & 1 & & 1 & \\
\hline & Very slight & & Very slight & & Very slight & & Very slight & & Very slight \\
\hline 2 & & 2 & & 2 & & 2 & & 2 & \\
\hline & Slight - & & Slight - & & Slight - & & Slight - & & Slight - \\
\hline 3 & & 3 & & 3 & & 3 & & 3 & \\
\hline & Somewhat & & Somewhat & & Somewhat & & Somewhat & & Somewhat \\
\hline high & 4 & high & 4 & high & 4 & high & 4 & high & 4 \\
\hline & High - & & High - & & High - & & High - & & High - \\
\hline 5 & & 5 & & 5 & & 5 & & 5 & \\
\hline & Unbearabl & & Unbearabl & & Unbearabl & & Unbearabl & & Unbearabl \\
\hline e & 6 & e & 6 & e & 6 & e & 6 & e & 6 \\
\hline
\end{tabular}


Study ID:
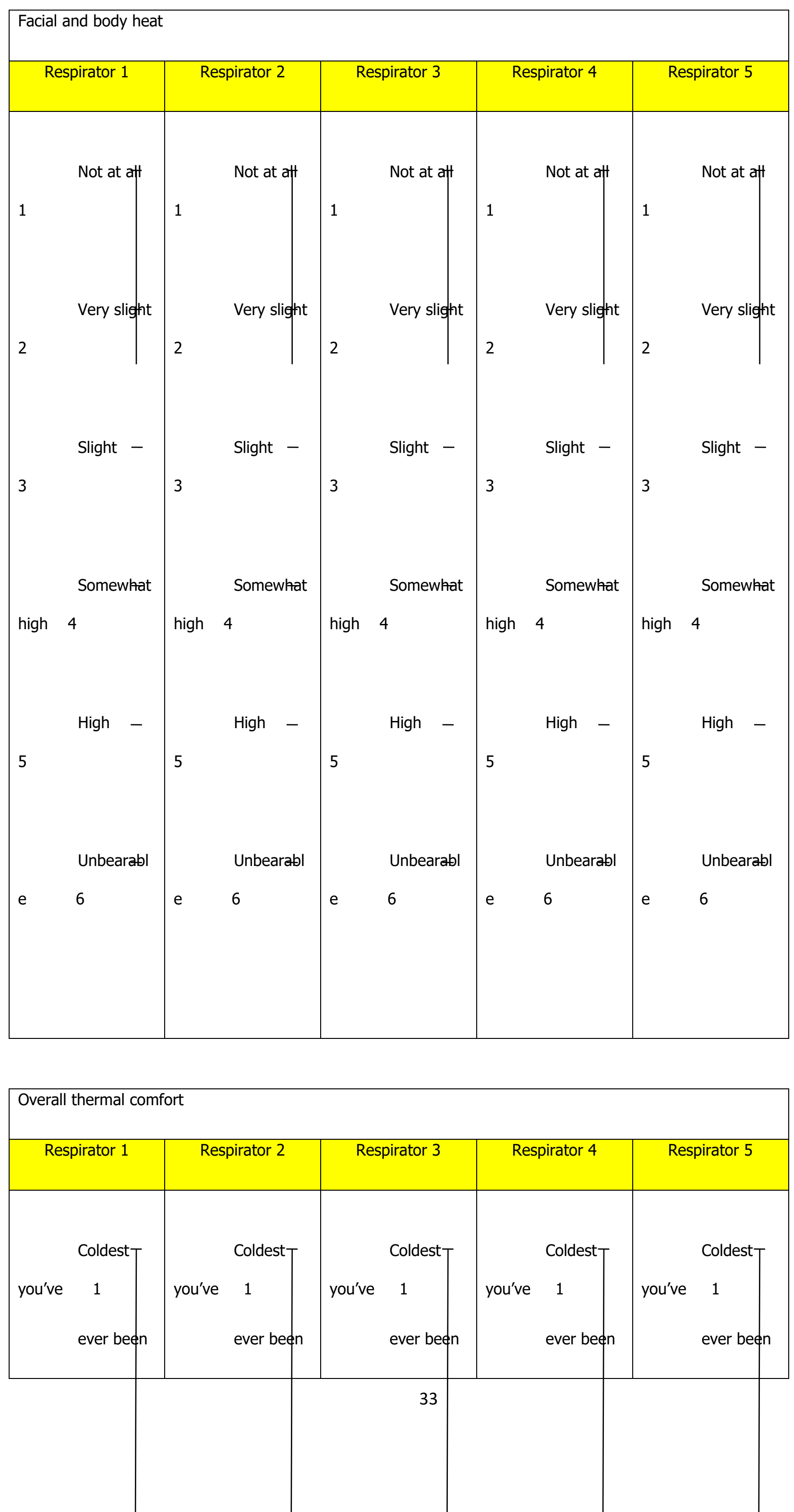


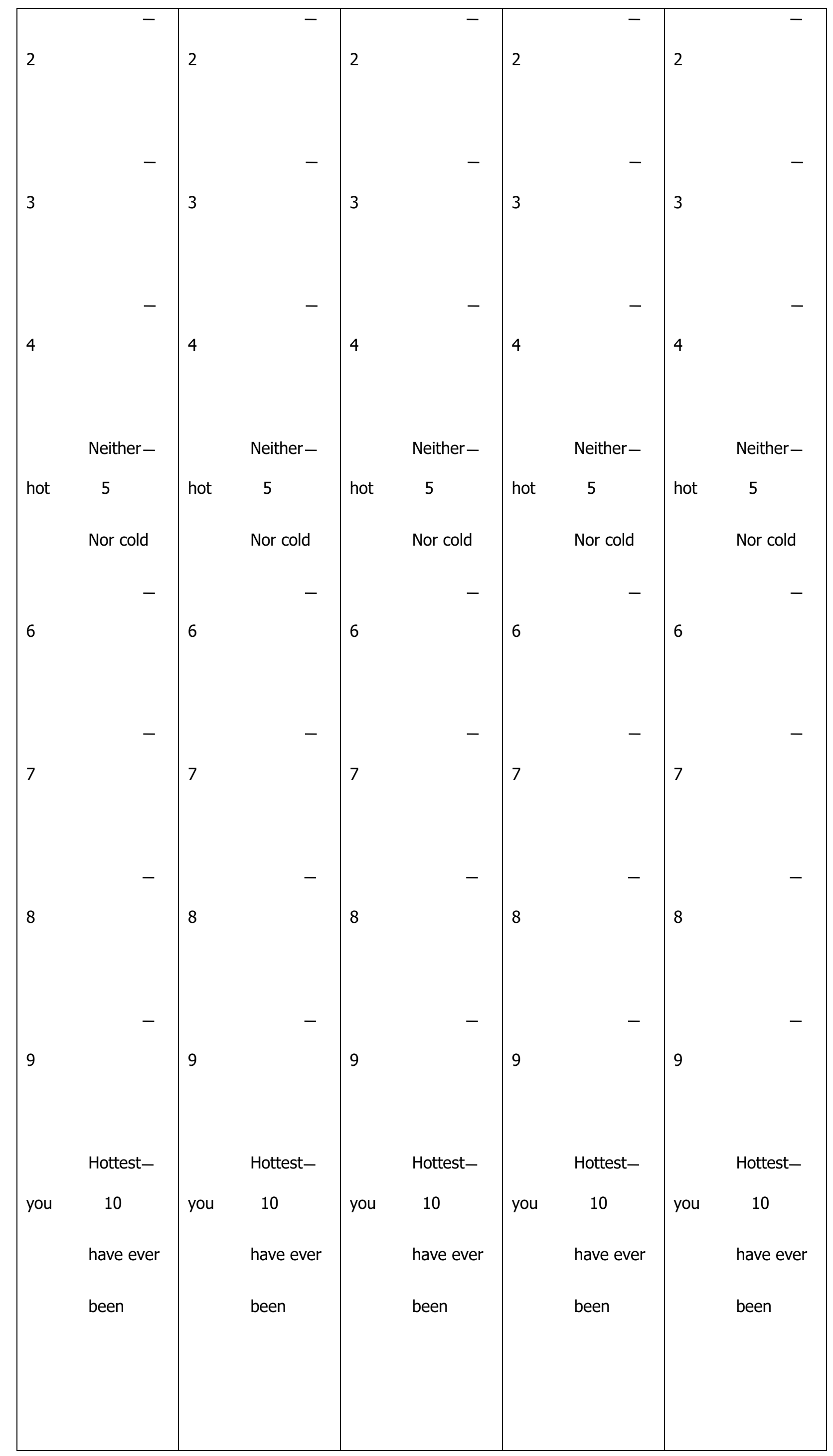


Study ID:
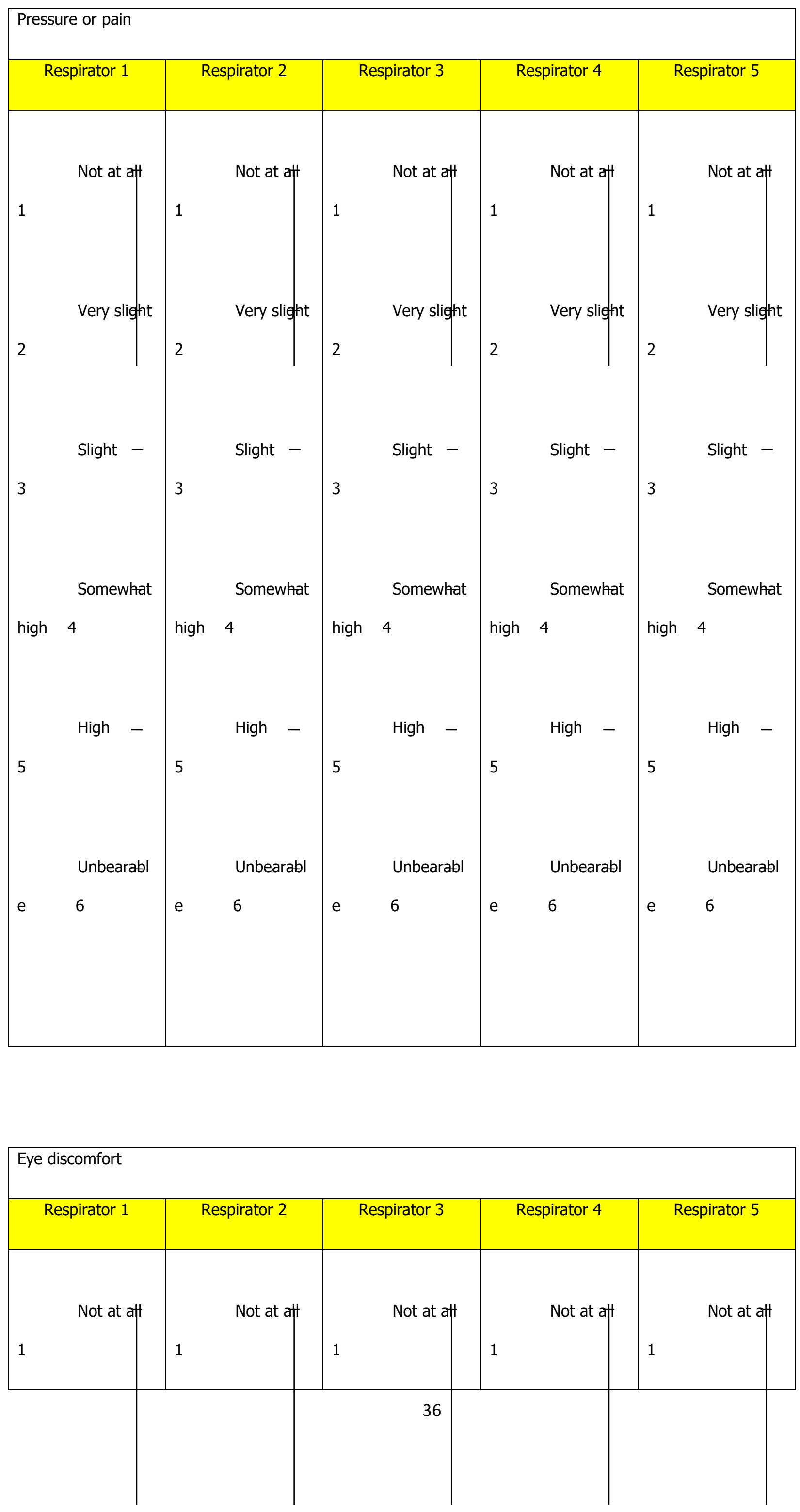


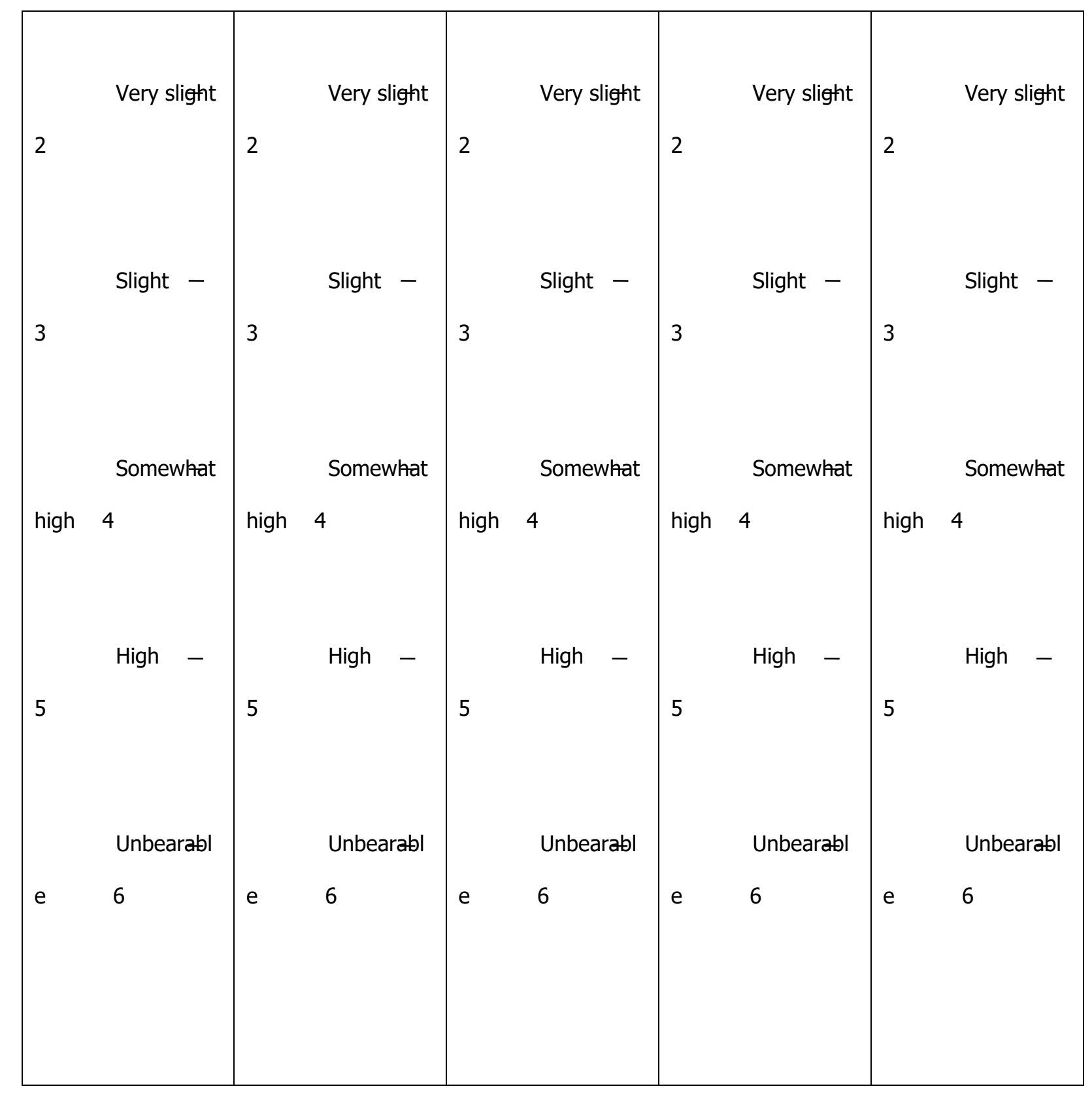

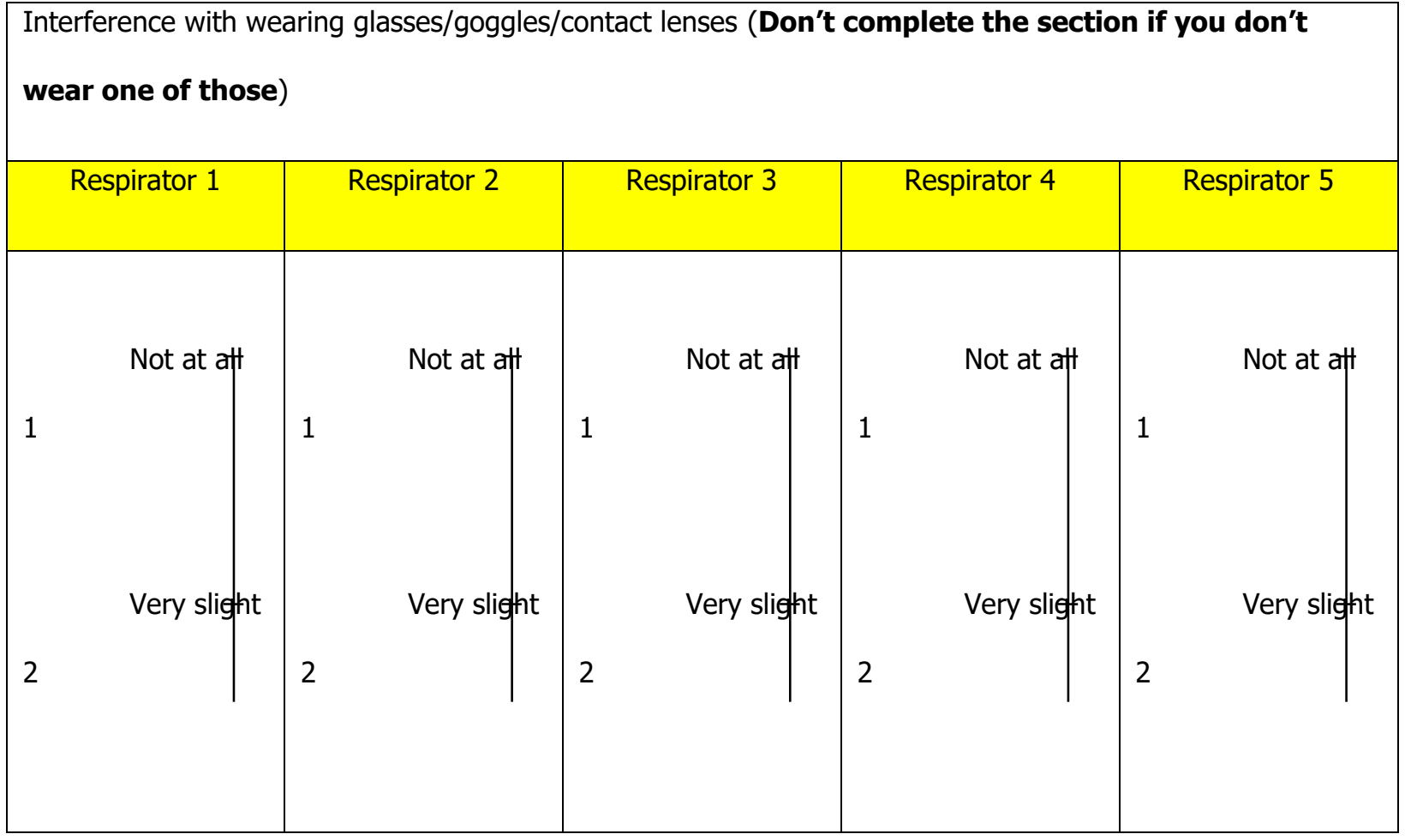




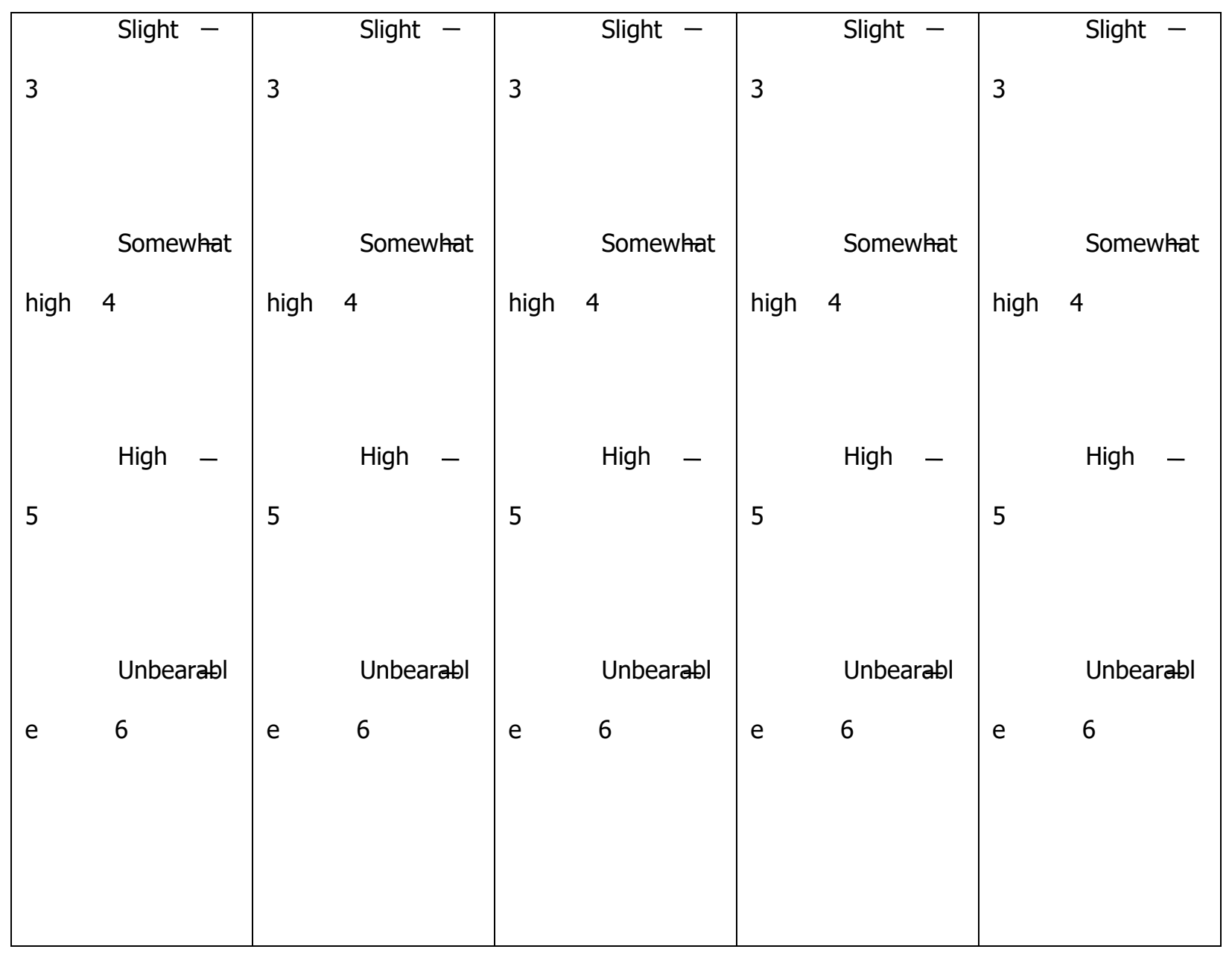


Study ID:

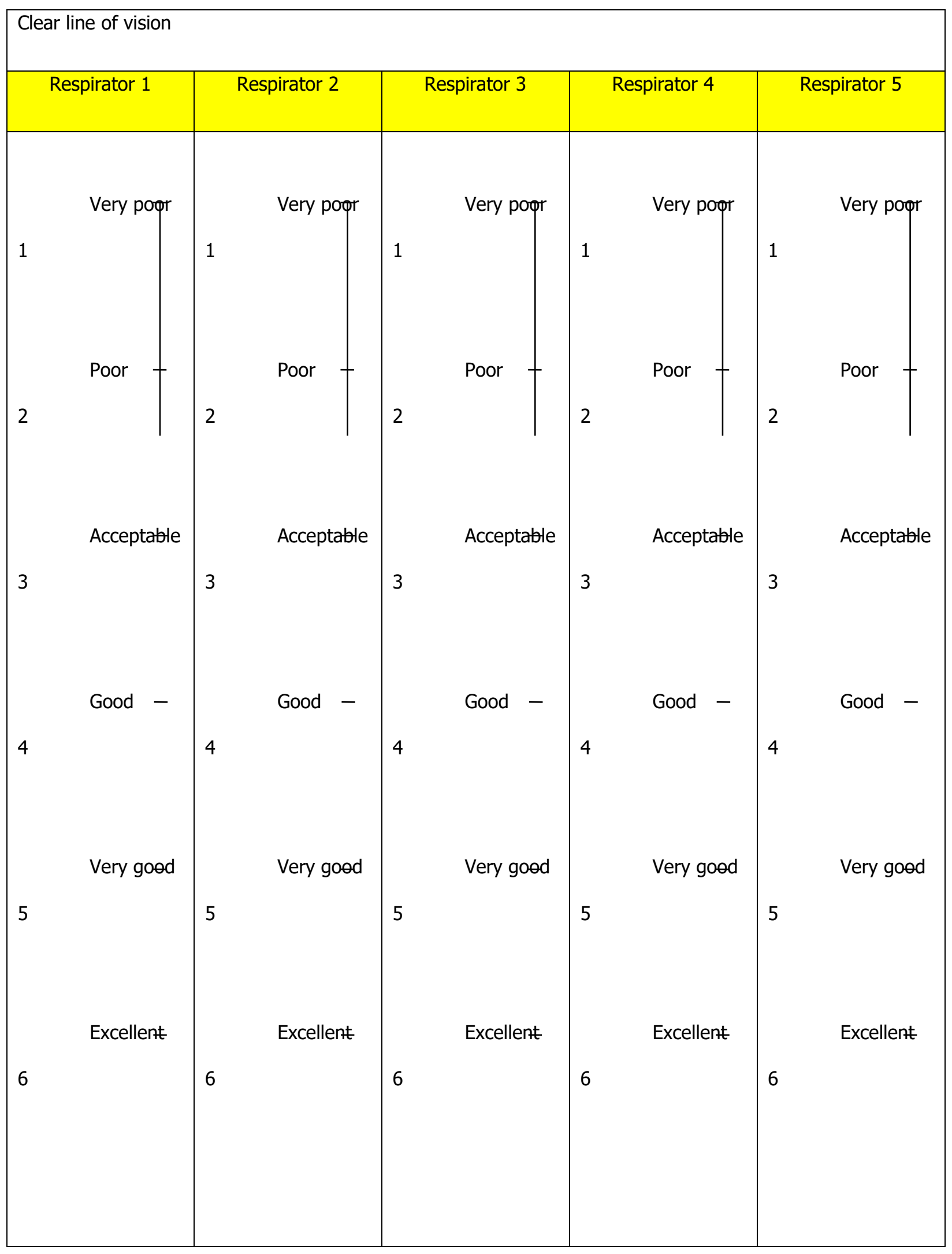

Difficulty of putting on

\begin{tabular}{|l|l|l|l|l|}
\hline Respirator 1 & Respirator 2 & Respirator 3 & Respirator 4 & Respirator 5 \\
\hline & & & & \\
\hline
\end{tabular}




\begin{tabular}{|c|c|c|c|c|c|c|c|c|c|}
\hline & Not at aft & \multicolumn{2}{|r|}{ Not at aft } & \multicolumn{2}{|r|}{ Not at aft } & \multicolumn{2}{|r|}{ Not at aft } & \multicolumn{2}{|r|}{ Not at aft } \\
\hline 1 & & 1 & & 1 & & 1 & & 1 & \\
\hline & Very slight & & Very slight & & Very slight & & Very slight & & Very slight \\
\hline 2 & & 2 & & 2 & & 2 & & 2 & \\
\hline & Slight - & & Slight - & & Slight - & & Slight - & & Slight - \\
\hline 3 & & 3 & & 3 & & 3 & & 3 & \\
\hline & Somewhat & & Somewhat & & Somewhat & & Somewhat & & Somewhat \\
\hline high & 4 & high & 4 & high & 4 & high & 4 & high & 4 \\
\hline & High - & & High - & & High - & & High - & & High - \\
\hline 5 & & 5 & & 5 & & 5 & & 5 & \\
\hline & Unbearabl & & Unbearabl & & Unbearabl & & Unbearabl & & Unbearabl \\
\hline e & 6 & e & 6 & e & 6 & e & 6 & e & 6 \\
\hline
\end{tabular}


Study ID:

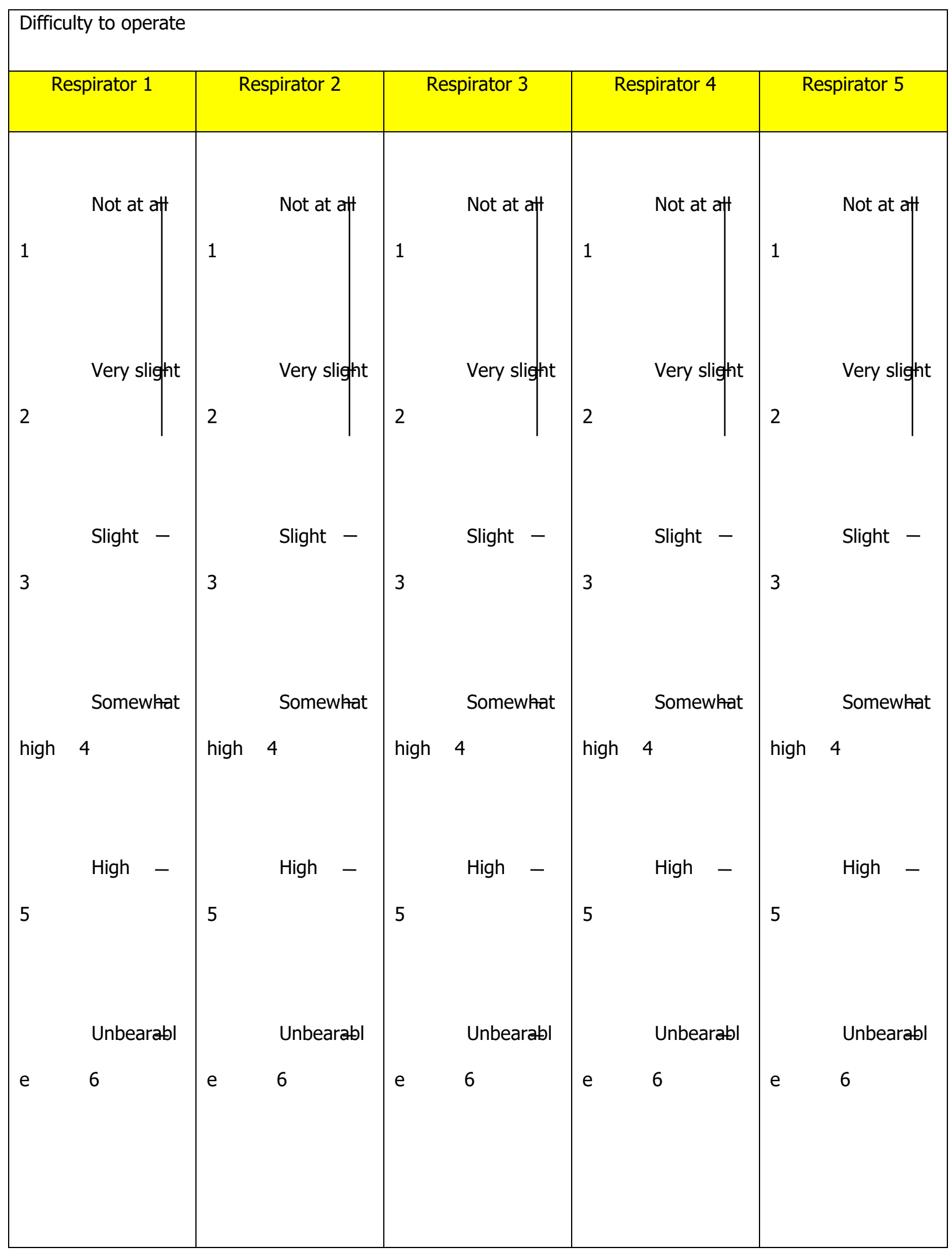

Mechanical interference with duties

\begin{tabular}{|l|l|l|l|l|}
\hline Respirator 1 & Respirator 2 & Respirator 3 & Respirator 4 & Respirator 5 \\
\hline & & & & \\
\hline
\end{tabular}




\begin{tabular}{|c|c|c|c|c|c|c|c|c|c|}
\hline & Not at aft & \multicolumn{2}{|r|}{ Not at aft } & \multicolumn{2}{|r|}{ Not at aft } & \multicolumn{2}{|r|}{ Not at aft } & \multicolumn{2}{|r|}{ Not at aft } \\
\hline 1 & & 1 & & 1 & & 1 & & 1 & \\
\hline & Very slight & & Very slight & & Very slight & & Very slight & & Very slight \\
\hline 2 & & 2 & & 2 & & 2 & & 2 & \\
\hline & Slight - & & Slight - & & Slight - & & Slight - & & Slight - \\
\hline 3 & & 3 & & 3 & & 3 & & 3 & \\
\hline & Somewhat & & Somewhat & & Somewhat & & Somewhat & & Somewhat \\
\hline high & 4 & high & 4 & high & 4 & high & 4 & high & 4 \\
\hline & High - & & High - & & High - & & High - & & High - \\
\hline 5 & & 5 & & 5 & & 5 & & 5 & \\
\hline & Unbearabl & & Unbearabl & & Unbearabl & & Unbearabl & & Unbearabl \\
\hline e & 6 & e & 6 & e & 6 & e & 6 & e & 6 \\
\hline
\end{tabular}


Study ID:

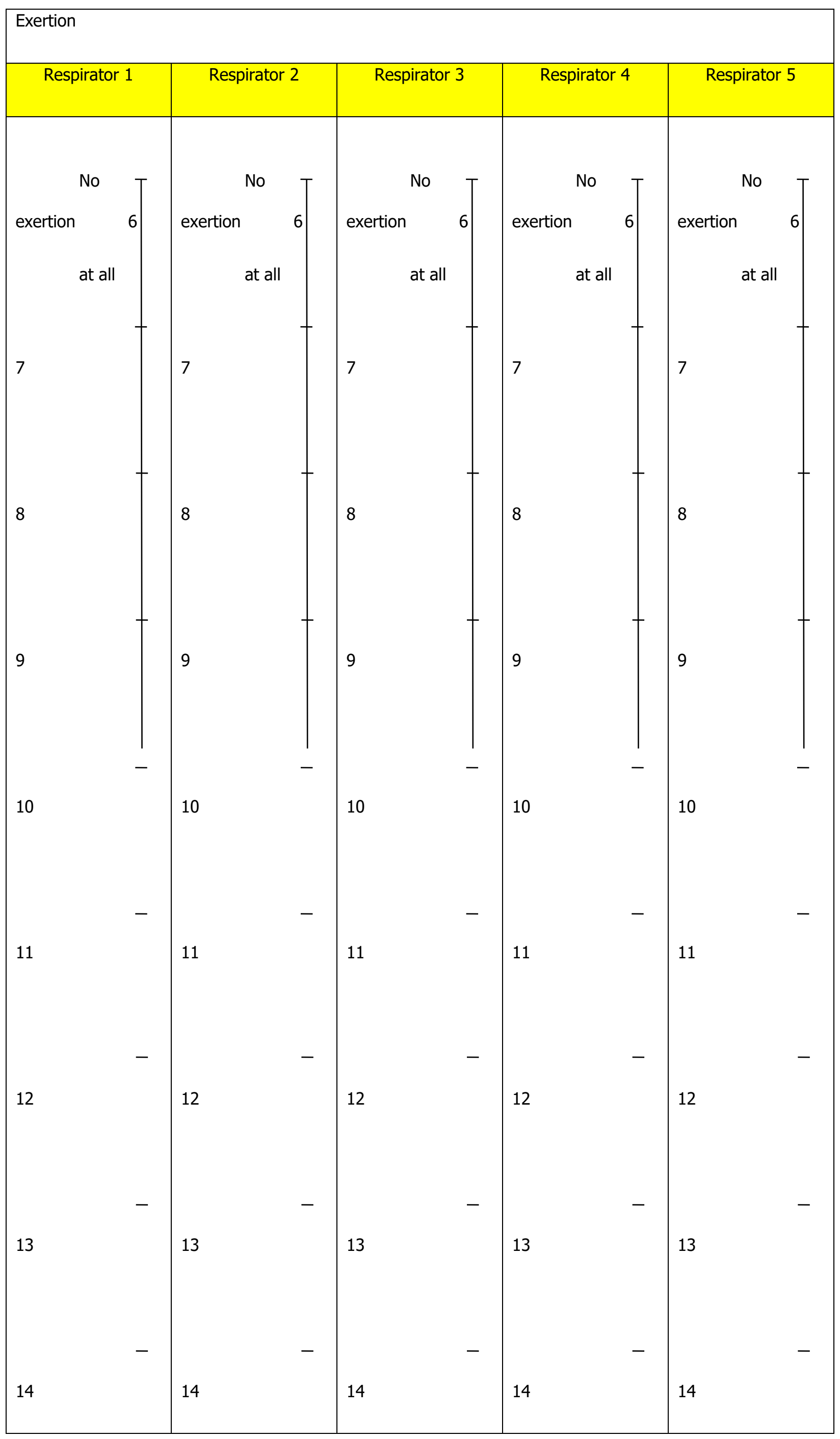




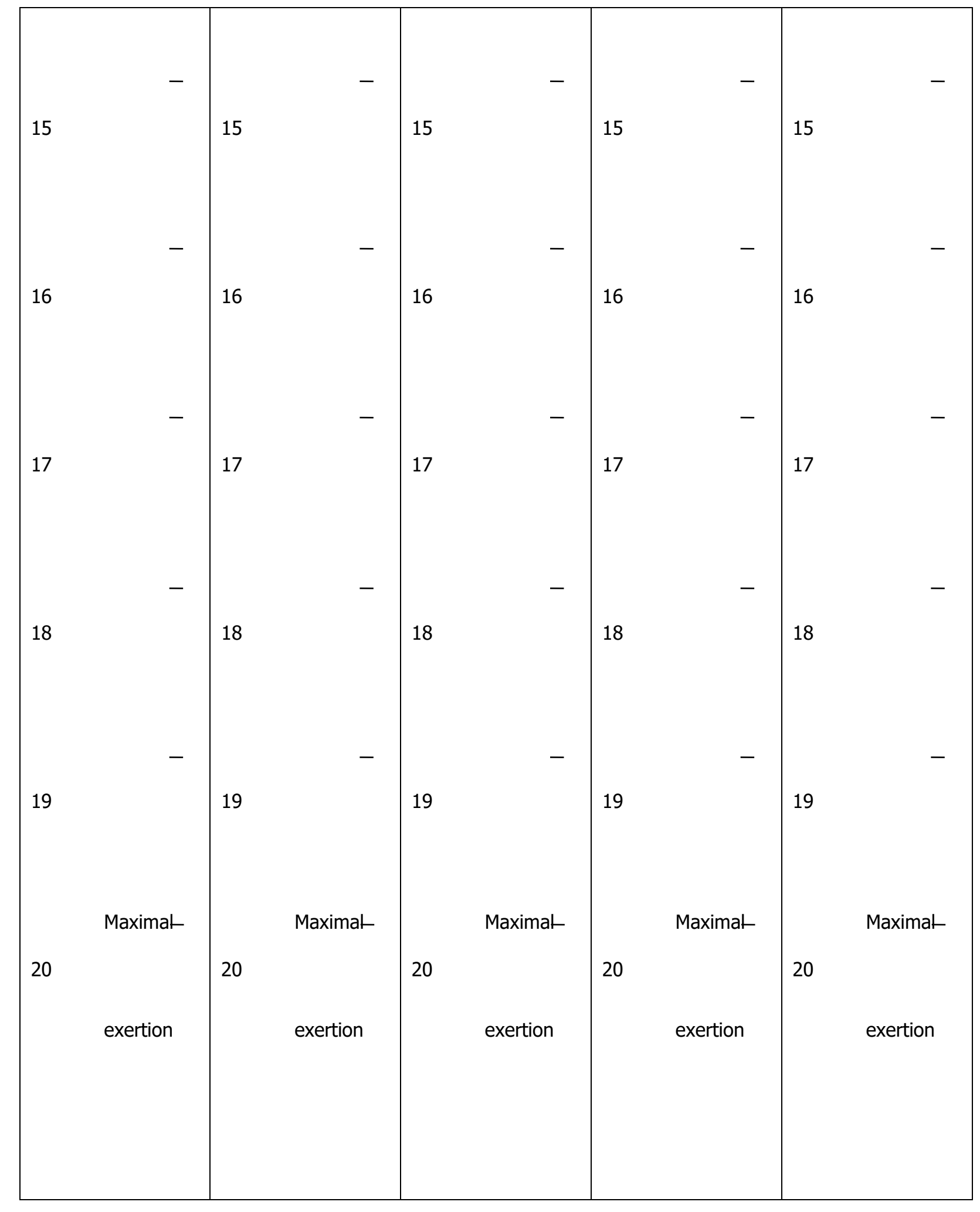

How many hours do you think you could wear this respirator continuously?

\begin{tabular}{|l|l|l|l|l|}
\hline Respirator 1 & Respirator 2 & Respirator 3 & Respirator 4 & Respirator 5 \\
\hline & & & & \\
\hline
\end{tabular}

Perceived efficiency against biological hazards

\begin{tabular}{|l|l|l|l|l|}
\hline Respirator 1 & Respirator 2 & Respirator 3 & Respirator 4 & Respirator 5 \\
\hline
\end{tabular}




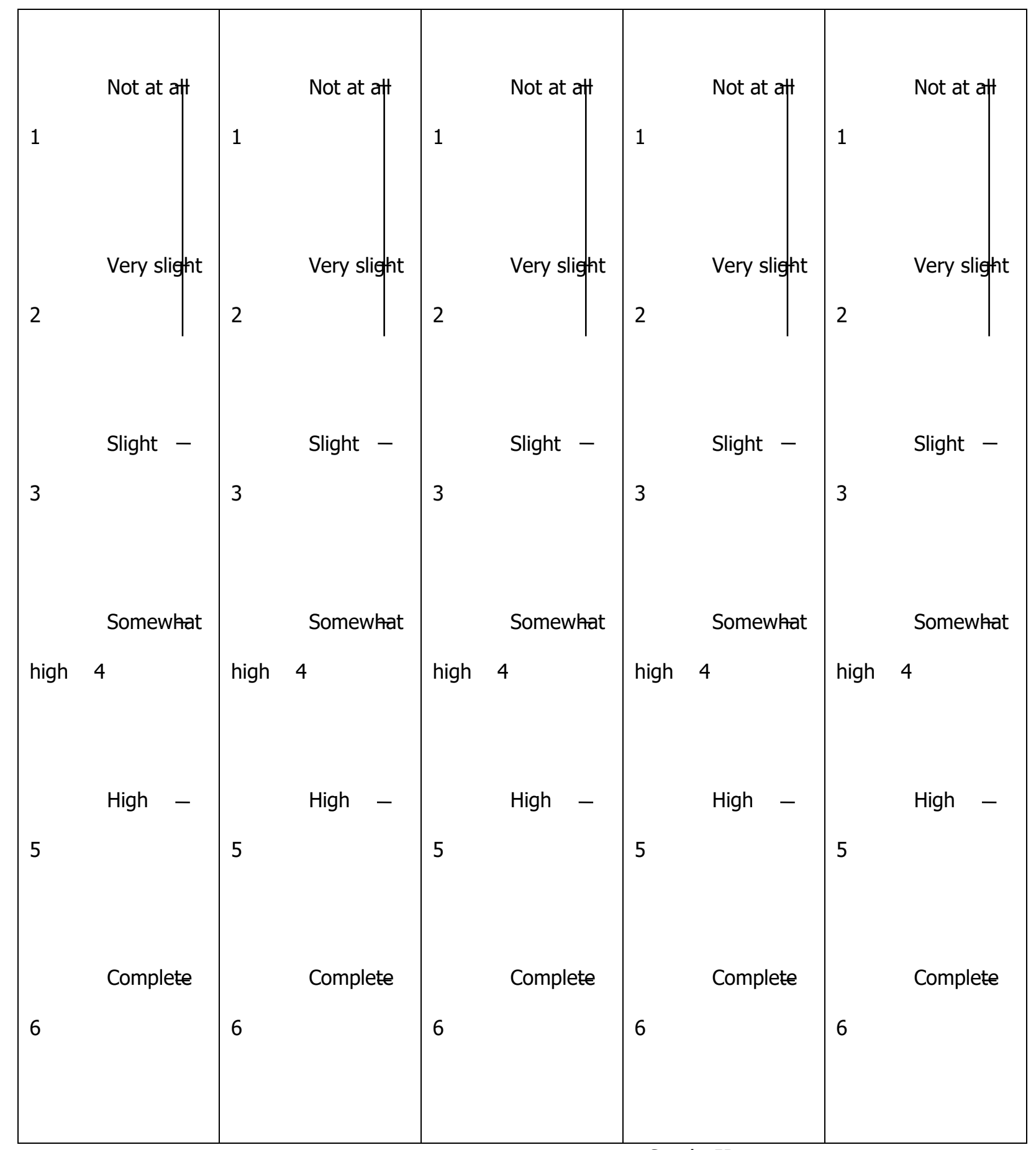

Study ID:

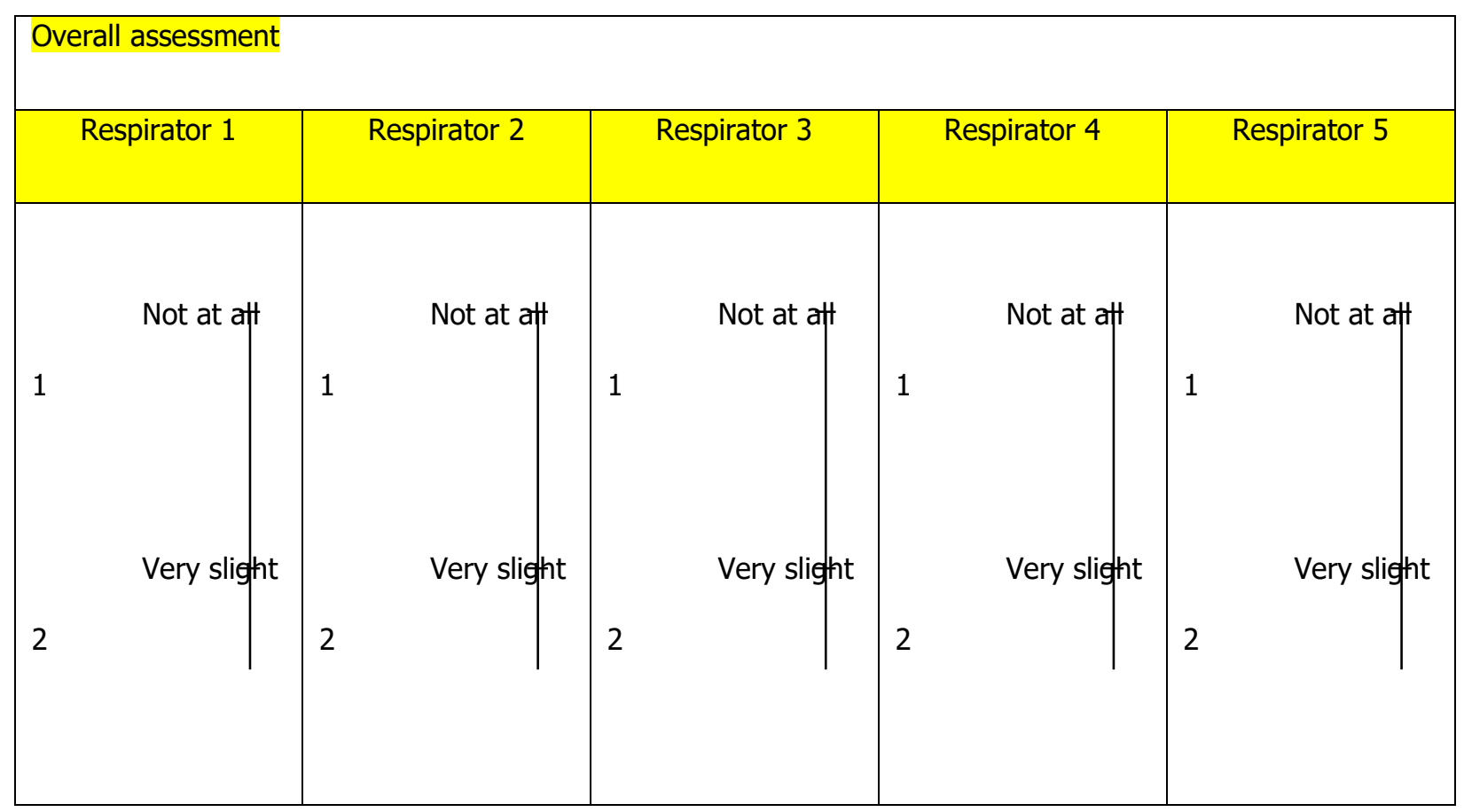




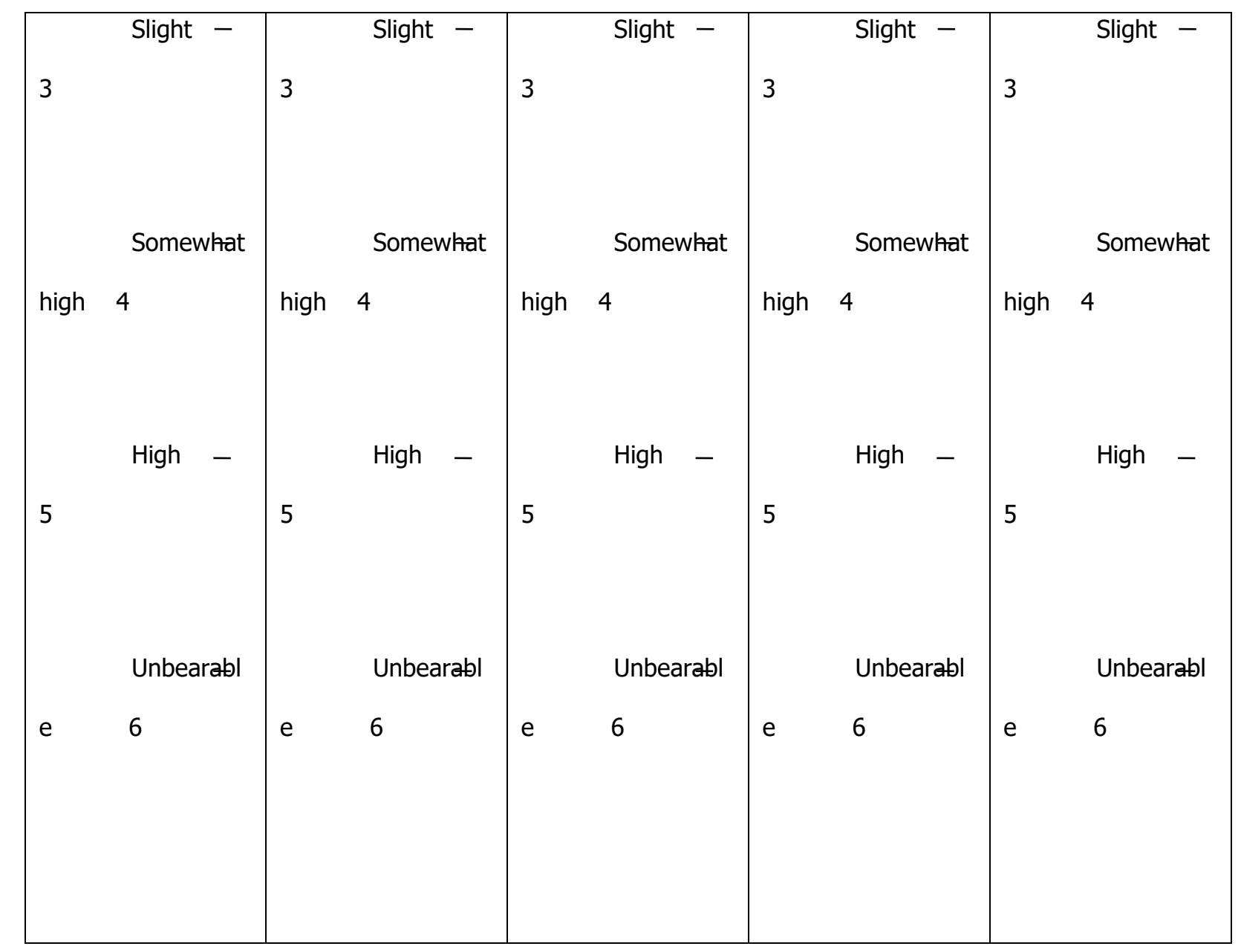

BEFORE TEST

\begin{tabular}{|c|c|c|c|c|}
\hline \multirow[t]{2}{*}{ RESPIRATOR TYPE } & \multicolumn{3}{|c|}{ VITAL SIGNS } & $\begin{array}{l}\text { EXPERIENCE OF USING ANY TYPE OF RESPIRATOR } \\
\text { BEFORE }\end{array}$ \\
\hline & $\begin{array}{l}\text { Heart Rate } \\
\text { (/mins) }\end{array}$ & $\begin{array}{l}\text { Respiratory } \\
\text { Rate(/mins) }\end{array}$ & $\mathrm{SpO2}$ & \\
\hline \multicolumn{5}{|l|}{ Respirator 1} \\
\hline \multicolumn{5}{|l|}{ Respirator 2} \\
\hline \multicolumn{5}{|l|}{ Respirator 3} \\
\hline \multicolumn{5}{|l|}{ Respirator 4} \\
\hline Respirator 5 & & & & \\
\hline
\end{tabular}

AFTER TEST

\begin{tabular}{|c|c|c|c|c|}
\hline \multirow[b]{2}{*}{ TYPE } & \multicolumn{3}{|c|}{ VITAL SIGNS } & \multirow[b]{2}{*}{$\begin{array}{l}\text { SPEECH } \\
\text { INTELLIGIBILITY TEST } \\
\text { (MRT) }\end{array}$} \\
\hline & $\begin{array}{l}\text { Heart } \\
\text { Rate (/mins) }\end{array}$ & $\begin{array}{l}\text { Respiratory } \\
\text { Rate(/mins) }\end{array}$ & $\begin{array}{ll} & \mathrm{SpO} 2 \\
(\%) & \end{array}$ & \\
\hline Respirator 1 & & & & \\
\hline
\end{tabular}




\begin{tabular}{|l|l|l|l|l|}
\hline Respirator 2 & & & & \\
\hline Respirator 3 & & & & \\
\hline Respirator 4 & & & & \\
\hline Respirator 5 & & & & \\
\hline
\end{tabular}


Study ID:

\section{QUESTIONNAIRE SURVEY}

\begin{tabular}{|c|c|c|c|c|c|}
\hline \multicolumn{6}{|c|}{ Evaluation on preference and acceptability comparing low flow rate with high flow rate for low-risk tasks } \\
\hline Questions & Versflow & Koken & $\begin{array}{c}\text { AIR } \\
\text { MATE }\end{array}$ & $\begin{array}{l}\text { MAX } \\
\text { AIR }\end{array}$ & N95 \\
\hline $\begin{array}{l}\text { When performing the following tasks (deemed low risks), do } \\
\text { you prefer a lower flow rate for the following PAPR? (yes and no for } \\
\text { each PAPR model) }\end{array}$ & & & & & $N / A$ \\
\hline $\begin{array}{l}\text { When performing the following tasks (deemed low risks), do } \\
\text { you think a lower flow rate is more acceptable? (yes and no for each } \\
\text { PAPR model) }\end{array}$ & & & & & N/A \\
\hline $\begin{array}{l}\text { When performing the following tasks (deemed low risks), do } \\
\text { you think a lower flow rate is more effective? (yes and no for each } \\
\text { PAPR model) }\end{array}$ & & & & & $N / A$ \\
\hline
\end{tabular}

\begin{tabular}{|c|c|c|c|c|c|}
\hline \multicolumn{6}{|c|}{ Evaluation on preference and acceptability comparing N95 FFR with evaluated PAPRs for low-risk tasks } \\
\hline Questions & Versflow & Koken & $\begin{array}{c}\text { AIR } \\
\text { MATE }\end{array}$ & $\begin{array}{l}\text { MAX } \\
\text { AIR }\end{array}$ & N95 \\
\hline $\begin{array}{l}\text { When performing the following tasks (deemed low risks), which type } \\
\text { of the following } 5 \text { respirators do you prefer to use? }\end{array}$ & & & & & \\
\hline $\begin{array}{l}\text { When performing the following tasks (deemed low risks), which type } \\
\text { of the following } 5 \text { respirators do you think is more acceptable? }\end{array}$ & & & & & \\
\hline $\begin{array}{l}\text { When performing the following tasks (deemed low risks), which type } \\
\text { of the following } 5 \text { respirators do you think is more effective? }\end{array}$ & & & & & \\
\hline
\end{tabular}

\begin{tabular}{|c|c|c|c|c|c|}
\hline \multicolumn{6}{|c|}{ Evaluation on preference and acceptability comparing N95 FFR with evaluated PAPRs for high-risk tasks } \\
\hline Questions & Versflow & Koken & $\begin{array}{l}\text { AIR } \\
\text { MATE }\end{array}$ & $\begin{array}{l}\text { MAX } \\
\text { AIR }\end{array}$ & N95 \\
\hline $\begin{array}{l}\text { When performing the following tasks (deemed high risks), which } \\
\text { type of the following } 5 \text { respirators do you prefer to use? }\end{array}$ & & & & & \\
\hline $\begin{array}{l}\text { When performing the following tasks (deemed high risks), which } \\
\text { type of the following } 5 \text { respirators do you think is more acceptable? }\end{array}$ & & & & & \\
\hline $\begin{array}{l}\text { When performing the following tasks (deemed high risks), which } \\
\text { type of the following } 5 \text { respirators do you think is more effective? }\end{array}$ & & & & & \\
\hline
\end{tabular}


Other symptoms

\begin{tabular}{|l|l|l|l|l|l|}
\hline $\begin{array}{l}\text { Somatic complaints for respirators } \\
\text { (Yes and No for each symptom) }\end{array}$ & $\begin{array}{l}\text { Respirator } \\
1\end{array}$ & Respirator 2 & Respirator 3 & $\begin{array}{l}\text { Respirator } \\
4\end{array}$ & $\begin{array}{l}\text { Respirator } \\
5\end{array}$ \\
\hline Nausea & & & & & \\
\hline Dizziness or difficult concentrating & & & & & \\
\hline Unusual smell/odor & & & & & \\
\hline Eye irritation signs (if any) & & & & \\
\hline
\end{tabular}

List of Tested Respirators:

\begin{tabular}{|c|c|c|c|c|}
\hline Respirator 1 & Respirator 2 & Respirator 3 & Respirator 4 & Respirator 5 \\
\hline & & & & \\
Versflow & Koken & AIR MATE & MAX AIR & N95 \\
& & & & \\
\hline
\end{tabular}

Other Comments: 


\section{Appendix C: Raw Data}

\section{C.1. Evaluation Categories}

\begin{tabular}{|c|c|c|c|c|c|c|c|c|c|}
\hline N95 & & & & & & & & & \\
\hline & Subject 001 & Subject 002 & Subject 003 & Subject 004 & & Subject 005 & Subject 006 & Subject 007 & Subject 008 \\
\hline General comfort & 2 & 3 & & 2 & 5 & 2 & 3 & 2 & 3 \\
\hline Inspiratory/expiratory effort & 4 & 5 & & 4 & 2 & 6 & 2 & 2 & 5 \\
\hline Overall breathing discomfort & 2 & 4 & & 4 & 2 & 5 & 2 & 2 & 4 \\
\hline Facial and body heat & 2 & 4 & & 4 & 2 & 5 & 2 & 4 & 5 \\
\hline Overall thermal comfort & 6 & 7 & & 7 & 6 & 7 & 5 & 5 & 10 \\
\hline Pressure or pain & 4 & 3 & & 3 & 2 & 4 & 2 & 3 & 1 \\
\hline Eye discomfort & 1 & 1 & & 1 & 1 & 1 & 1 & 1 & 1 \\
\hline $\begin{array}{l}\text { Interference with wearing } \\
\text { glasses/goggles/contacts }\end{array}$ & 1 & & N/A & & 1 & 1 & 1 & & $2 \mathrm{~N} / \mathrm{A}$ \\
\hline Clear line of vision & 5 & 5 & & 6 & 6 & 5 & 5 & 5 & 5 \\
\hline Difficulty of putting on & 1 & 2 & & 1 & 1 & 1 & 2 & 1 & 1 \\
\hline Difficulty to operate & 1 & 1 & & 1 & 1 & 1 & 1 & 1 & 1 \\
\hline $\begin{array}{c}\text { Mechanical interference with } \\
\text { duties }\end{array}$ & 2 & 1 & & 1 & 1 & 1 & 1 & 1 & 1 \\
\hline Exertion & 14 & 14 & & 9 & 6 & 12 & 7 & 13 & 6 \\
\hline $\begin{array}{l}\text { How many hours could you } \\
\text { wear this respiratory } \\
\text { continuously? }\end{array}$ & 1 & 0.5 & & 1 & 12 & 2 & 2 & 1 & 1 \\
\hline $\begin{array}{l}\text { Perceived efficiency against } \\
\text { biological hazards }\end{array}$ & 3 & 4 & & 4 & 6 & 6 & 3 & 4 & 4 \\
\hline Overall assessment & 3 & 5 & & 4 & 2 & 4 & 2 & 4 & 4 \\
\hline
\end{tabular}

\begin{tabular}{|c|c|c|c|c|c|c|c|}
\hline Subject 009 & Subject 010 & Subject 011 & Subject 012 & Subject 013 & Subject 014 & Subject 015 & Subject 016 \\
\hline 3 & 3 & 5 & 1 & 3 & 2 & 3 & 3 \\
\hline 3 & 1 & 1 & 7 & 5 & 5 & 3 & 2 \\
\hline 2 & 2 & 1 & 5 & 3 & 5 & 3 & 2 \\
\hline 4 & 3 & 2 & 6 & 5 & 5 & 4 & 2 \\
\hline 7 & 5 & 5 & 8 & 7 & 8 & 6 & 6 \\
\hline 3 & 1 & 2 & 4 & 1 & 1 & 1 & 3 \\
\hline 3 & 1 & 1 & 1 & 1 & 4 & 1 & 1 \\
\hline 3 & 1 & 1 & 1 & N/A & 5 & $N / A$ & 3 \\
\hline 4 & 4 & 5 & 6 & 5 & 2 & 6 & 4 \\
\hline 3 & 1 & 1 & 1 & 2 & 1 & 1 & 1 \\
\hline 1 & 1 & 1 & 1 & 1 & 3 & 1 & 1 \\
\hline 2 & 1 & 1 & 1 & 1 & 4 & 1 & 2 \\
\hline 11 & 6 & 6 & 10 & 10 & 10 & 7 & 8 \\
\hline 2 & 1 & 2 & 0.05 & 1.5 & 1 & 1 & 5 \\
\hline 2 & 3 & 3 & 4 & 2 & 1 & 3 & 4 \\
\hline 3 & 4 & 2 & 6 & 3 & 4 & 4 & 4 \\
\hline
\end{tabular}




\begin{tabular}{|c|c|c|c|c|c|c|c|c|}
\hline \multirow{2}{*}{ Versflow (PAPR) } & & & & & \multirow[b]{2}{*}{ Subject 005} & \multirow[b]{2}{*}{ Subject 006} & \multirow[b]{2}{*}{ Subject 007} & \multirow[b]{2}{*}{ Subject 008} \\
\hline & Subject 001 & Subject 002 & Subject 003 & Subject 004 & & & & \\
\hline General comfort & 2 & 1 & 2 & 3 & 1 & 3 & 4 & 5 \\
\hline Inspiratory/expiratory effort & 4 & 5 & 4 & 2 & 2 & 2 & 2 & 1 \\
\hline Overall breathing discomfort & 3 & 4 & 4 & 2 & 5 & 1 & 2 & 1 \\
\hline Facial and body heat & 1 & 5 & 5 & 2 & 5 & 2 & 3 & 1 \\
\hline Overall thermal comfort & 3 & 7 & 8 & 5 & 8 & 5 & 6 & 2 \\
\hline Pressure or pain & 5 & 1 & 2 & 1 & 3 & 3 & 2 & 1 \\
\hline Eye discomfort & 1 & 1 & 3 & 1 & 3 & 2 & 2 & 1 \\
\hline $\begin{array}{l}\text { Interference with wearing } \\
\text { glasses/goggles/contacts }\end{array}$ & 1 & & N/A & 1 & 2 & 2 & 3 & N/A \\
\hline Clear line of vision & 3 & 3 & 2 & 4 & 4 & 3 & 4 & 4 \\
\hline Difficulty of putting on & 5 & 3 & 4 & 4 & 3 & 3 & 2 & 1 \\
\hline Difficulty to operate & 5 & 4 & 3 & 4 & 5 & 3 & 2 & 1 \\
\hline $\begin{array}{c}\text { Mechanical interference with } \\
\text { duties }\end{array}$ & 5 & 4 & 4 & 3 & 5 & 3 & 2 & 2 \\
\hline Exertion & 17 & 12 & 10 & 8 & 17 & 8 & 9 & 6 \\
\hline $\begin{array}{l}\text { How many hours could you } \\
\text { wear this respiratory }\end{array}$ & & & & & & & & \\
\hline continuously? & 1 & 1 & 2 & 2 & 0.25 & 2 & 3 & 2 \\
\hline Perceived efficiency against & & & & & & & & \\
\hline biological hazards & 3 & 3 & 5 & 6 & 3 & 3 & 3 & 3 \\
\hline Overall assessment & 5 & 5 & 5 & 3 & 5 & 3 & 2 & 1 \\
\hline
\end{tabular}

\begin{tabular}{|c|c|c|c|c|c|c|c|}
\hline Subject 009 & Subject 010 & Subject 011 & Subject 012 & Subject 013 & Subject 014 & Subject 015 & Subject 016 \\
\hline 5 & 2 & 2 & 3 & 3 & 4 & 2 & 4 \\
\hline 2 & 2 & 1 & 4 & 1 & 1 & 2 & 1 \\
\hline 2 & 2 & 2 & 1 & 1 & 1 & 1 & 1 \\
\hline 3 & 4 & 1 & 1 & 2 & 1 & 3 & 1 \\
\hline 6 & 7 & 5 & 4 & 5 & 5 & 5 & 5 \\
\hline 1 & 1 & 3 & 1 & 1 & 1 & 1 & 2 \\
\hline 1 & 3 & 1 & 1 & 1 & 1 & 1 & 1 \\
\hline 1 & 3 & 3 & 1 & N/A & 1 & N/A & 2 \\
\hline 4 & 2 & 2 & 3 & 3 & 4 & 5 & 4 \\
\hline 3 & 5 & 4 & 3 & 4 & 3 & 4 & 2 \\
\hline 3 & 5 & 4 & 2 & 3 & 1 & 2 & 2 \\
\hline 2 & 5 & 4 & 2 & 3 & 1 & 4 & 3 \\
\hline 8 & 6 & 9 & 10 & 8 & 8 & 6 & 8 \\
\hline 4 & 0.25 & 1 & 0.2 & 3 & 1.5 & 2 & 6 \\
\hline 5 & 3 & 4 & 5 & 4 & 2 & 3 & 5 \\
\hline 2 & 5 & 5 & 2 & 2 & 2 & 3 & 5 \\
\hline
\end{tabular}




\begin{tabular}{|c|c|c|c|c|c|c|c|c|}
\hline \multicolumn{9}{|l|}{ MAX AIR (PAPR) } \\
\hline & Subject 001 & Subject 002 & Subject 003 & Subject 004 & Subject 005 & Subject 006 & Subject 007 & Subject 008 \\
\hline General comfort & 5 & 3 & 5 & 5 & 6 & 4 & 5 & 5 \\
\hline Inspiratory/expiratory effort & 1 & 1 & 2 & 2 & 1 & 1 & 2 & 1 \\
\hline Overall breathing discomfort & 1 & 2 & 1 & 2 & 1 & 1 & 1 & 1 \\
\hline Facial and body heat & 2 & 2 & 3 & 2 & 1 & 2 & 2 & 1 \\
\hline Overall thermal comfort & 5 & 4 & 7 & 5 & 5 & 5 & 5 & 4 \\
\hline Pressure or pain & 3 & 1 & 1 & 1 & 1 & 2 & 1 & 1 \\
\hline Eye discomfort & 1 & 1 & 1 & 1 & 1 & 2 & 3 & 1 \\
\hline $\begin{array}{l}\text { Interference with wearing } \\
\text { glasses/goggles/contacts }\end{array}$ & 1 & & $\mathrm{~N} / \mathrm{A}$ & 1 & 1 & 1 & & N/A \\
\hline Clear line of vision & 4 & 3 & 6 & 5 & 6 & 4 & 4 & 5 \\
\hline Difficulty of putting on & 4 & 3 & 3 & 2 & 1 & 2 & 2 & 3 \\
\hline Difficulty to operate & 3 & 3 & 1 & 2 & 1 & 2 & 2 & 1 \\
\hline $\begin{array}{c}\text { Mechanical interference with } \\
\text { duties }\end{array}$ & 2 & 3 & 2 & 1 & 1 & 2 & 2 & 4 \\
\hline Exertion & 10 & 12 & 8 & 6 & 6 & 7 & 7 & 6 \\
\hline $\begin{array}{l}\text { How many hours could you } \\
\text { wear this respiratory } \\
\text { continuously? }\end{array}$ & 2 & 2 & 4 & 8 & 4 & 3 & 4 & 2 \\
\hline $\begin{array}{l}\text { Perceived efficiency against } \\
\text { biological hazards }\end{array}$ & 4 & 4 & 6 & 5 & 5 & 3 & 3 & 3 \\
\hline Overall assessment & 3 & 3 & 2 & 2 & 1 & 2 & 2 & ? \\
\hline
\end{tabular}

\begin{tabular}{|c|c|c|c|c|c|c|c|}
\hline Subject 009 & Subject 010 & Subject 011 & Subject 012 & Subject 013 & Subject 014 & Subject 015 & Subject 016 \\
\hline 4 & 3 & 3 & 2 & 3 & 4 & 4 & 4 \\
\hline 2 & 2 & 1 & 2 & 1 & 2 & 1 & 1 \\
\hline 1 & 2 & 1 & 1 & 1 & 1 & 1 & 1 \\
\hline 2 & 2 & 3 & 1 & 2 & 4 & 2 & 1 \\
\hline 5 & 5 & 6 & 5 & 5 & 7 & 5 & 5 \\
\hline 2 & 1 & 1 & 5 & 2 & 1 & 1 & 2 \\
\hline 1 & 1 & 1 & 1 & 1 & 1 & 1 & 1 \\
\hline 1 & 1 & 1 & 2 & $\mathrm{~N} / \mathrm{A}$ & 2 & $N / A$ & 2 \\
\hline 4 & 4 & 5 & 2 & 3 & 4 & 5 & 5 \\
\hline 2 & 3 & 1 & 2 & 4 & 1 & 2 & 1 \\
\hline 2 & 3 & 1 & 1 & 3 & 1 & 2 & 1 \\
\hline 3 & 2 & 2 & 4 & 4 & 1 & 3 & 2 \\
\hline 8 & 6 & 7 & 13 & 10 & 6 & 8 & 8 \\
\hline 4 & 1 & 1 & 0.15 & 2 & 1.5 & 2 & 6 \\
\hline 5 & 3 & 5 & 2 & 4 & 2 & 3 & 4 \\
\hline 2 & 5 & 2 & 2 & 3 & 4 & 3 & 4 \\
\hline
\end{tabular}

\begin{tabular}{|c|c|c|c|c|c|c|c|c|c|}
\hline AIR MATE (PAPR) & & & & & & & & & \\
\hline & Subject 001 & Subject 002 & Subject 003 & & Subject 004 & Subject 005 & Subject 006 & Subject 007 & Subject 008 \\
\hline General comfort & 3 & 4 & & 4 & 3 & 4 & 3 & 5 & 5 \\
\hline Inspiratory/expiratory effort & 1 & 4 & & 2 & 2 & 3 & 1 & 2 & 1 \\
\hline Overall breathing discomfort & 1 & 3 & & 2 & 2 & 2 & 1 & 2 & 1 \\
\hline Facial and body heat & 1 & 3 & & 3 & 4 & 2 & 2 & 2 & 1 \\
\hline Overall thermal comfort & 5 & 5 & & 5 & 7 & 5 & 5 & 5 & 4 \\
\hline Pressure or pain & 3 & 1 & & 2 & 1 & 1 & 2 & 1 & 1 \\
\hline Eye discomfort & 1 & 1 & & 2 & 1 & 1 & 2 & 1 & 1 \\
\hline $\begin{array}{l}\text { Interference with wearing } \\
\text { glasses/goggles/contacts }\end{array}$ & 1 & & N/A & & 1 & 1 & 2 & & N/A \\
\hline Clear line of vision & 3 & 3 & & 3 & 5 & 4 & 3 & 3 & 2 \\
\hline Difficulty of putting on & 3 & 3 & & 3 & 4 & 5 & 2 & 2 & 3 \\
\hline Difficulty to operate & 3 & 3 & & 2 & 4 & 2 & 2 & 1 & 1 \\
\hline $\begin{array}{c}\text { Mechanical interference with } \\
\text { duties }\end{array}$ & 3 & 2 & & 2 & 3 & 2 & 3 & 1 & 1 \\
\hline Exertion & 12 & 12 & & 9 & 10 & 8 & 7 & 8 & 6 \\
\hline $\begin{array}{l}\text { How many hours could you } \\
\text { wear this respirator } \\
\text { continuously? }\end{array}$ & & & & 3 & 1 & 2 & 3 & 4 & 1 \\
\hline $\begin{array}{l}\text { Continuously? } \\
\text { Perceived efficiency against }\end{array}$ & 1 & 2 & & 3 & 1 & 2 & & 4 & \\
\hline biological hazards & 3 & 4 & & 5 & 5 & 5 & 3 & 3 & 3 \\
\hline Overall assessment & 2 & 3 & & 3 & 3 & 3 & 3 & 2 & 1 \\
\hline
\end{tabular}




\begin{tabular}{|c|c|c|c|c|c|c|c|}
\hline Subject 009 & Subject 010 & Subject 011 & Subject 012 & Subject 013 & Subject 014 & Subject 015 & Subject 016 \\
\hline 3 & 4 & 3 & 2 & 3 & 4 & 3 & 4 \\
\hline 3 & 1 & 1 & 4 & 1 & 3 & 3 & 1 \\
\hline 3 & 1 & 1 & 1 & 1 & 1 & 3 & 1 \\
\hline 3 & 1 & 1 & 2 & 2 & 3 & 4 & 1 \\
\hline 6 & 5 & 5 & 3 & 5 & 6 & 6 & 5 \\
\hline 2 & 1 & 1 & 1 & 1 & 1 & 1 & 2 \\
\hline 4 & 1 & 1 & 4 & 1 & 1 & 1 & 1 \\
\hline 4 & 1 & 1 & 4 & N/A & 3 & $N / A$ & 2 \\
\hline 3 & 5 & 6 & 4 & 3 & 3 & 5 & 4 \\
\hline 4 & 2 & 2 & 2 & 3 & 1 & 2 & 2 \\
\hline 3 & 2 & 2 & 1 & 3 & 1 & 2 & 2 \\
\hline 4 & 1 & 4 & 4 & 4 & 1 & 3 & 3 \\
\hline 13 & 6 & 6 & 10 & 8 & 6 & 7 & 8 \\
\hline 1 & 2 & 1 & 0.2 & 3 & 1.5 & 2 & 4 \\
\hline 5 & 3 & 4 & 1 & 4 & 1 & 3 & 4 \\
\hline 3 & 5 & 2 & 4 & 2 & 3 & 4 & 4 \\
\hline
\end{tabular}

